The Bang Bang House and the Measure House: Poetic and Performative Architectures of Softness

\title{
Matthew Butcher
}

\section{Introduction}

The exploration in this article has been driven by a deep concern that we are becoming increasingly disembodied and disenchanted from our experience and understanding of the material and physical world, as well as the environments we inhabit. A condition which, it could be argued, has led directly to the damage that is currently being done to our environment through our on-going reliance on the use of fossil fuels and the overuse of natural resources. $^{1}$

One of the key ways that this disembodiment and disenchantment manifests itself is in the way we continue to reduce our understanding of the behaviours of climate and weather primarily to data. It is a condition that is examined by geographer and climate commentator Mike Hulme in his book Why We Disagree About Climate Change (2009), ${ }^{2}$ where he argues that misunderstandings about climate change are confounded by the continual abstraction of what climate change is and how it is measured. For Hulme this problem can be attributed to trends within environmental science to condense climate to a universal and global entity dissociated from how we actually experience weather on a daily basis, at the local level. In support of this, quoting earth scientists Clark A. Miller and Paul N. Edwards, he states that 'Climate now connotes "less the weather of any particular place than something more closely akin to the global environment: a natural object to be understood, investigated and managed on planetary scales". And this investigation and management requires the skills of the planetary scientist. ${ }^{3}$ In seeing climate as other, and not associated with the weather we experience, we have become detached from a clear conception of it and how it affects our daily lives. Climate thus remains in the realm of the statistical and mathematical, and not the physical. ${ }^{4}$ 
This situation of reducing our knowledge and experience of the world to technological readings and data is also having significant effects in the practice and discipline of architecture. Within the context of a more sustainable design ethos, architects' decisions around the buildings they are proposing and building are being formed through heavy regulatory requirements. Requirements that seek to insure the focus of design decisions is based on the efficiency of a building's ability to mitigate and control climate around strict parameters of what is determined to be comfortable and efficient. Parameters that prioritise the retention of heat in the winter and provoke sustained cooling in the summer. ${ }^{5}$

Further, in the name of efficiency we are also increasingly seeing buildings becoming designed as automated entities, with heating and cooling systems controlled by centralised and sometimes even remote computer systems that follow specific parameters based on governmental and regulatory standards. ${ }^{6}$ Within these environments, we have become generalised and inactive bodies; cut off and desensitised from a direct relationship to the outside environment. A condition which means increasingly we no longer have control, or individual agency, in mediating these interior spaces with the exterior world. ${ }^{7}$

Within this context, the central aim of this article is to ask how we might develop architectures that seek to negate the distance that has developed between the realities of the physical and material world, and the way we understand and experience it, including the conditions of a dramatically shifting climate. In addition, the article proposes that instead of reducing our experience of the spaces we inhabit and our environments to a Cartesian rigidity defined by data, that we return instead to the realm of the poetic. In this capacity, the essay builds on the thoughts of Historian Alberto PérezGómez in his book Architecture and the Crisis of Modern Science. ${ }^{8}$ PérezGómez sets out his argument that architecture's insistence on functionalist logics, including those manifesting an emphasis on technological reasoning, have prevented the discipline from exploring conditions of the poetic; limiting its ability to engage with and create a meaningful experience of the world. In the introduction to the book, Gómez argues, 'Because positivistic thought has 
made it a point to exclude mystery and poetry, contemporary man lives with the illusion of the infinite power of reason. He has forgotten his fragility and his capacity for wonder, generally assuming that all the phenomena of his world $[\ldots]$ have been "explained".,9

Instead, by focusing on architecture's poetic potential, this article will present a unique and provocative architectural response to how the discipline should engage with the challenges of climate change. It is a response that reengages our capacity to experience our own brittleness and that of the world; a condition that seeks to manifest a greater emotional resonance between those inhabiting any architecture and the environment.

The definition of the poetic I will use within this article will draw directly from Max Kozloff's essay 'The Poetics of Softness', published in 1967 as part of the catalogue for the 'American Sculpture of the Sixties' exhibition at the Los Angeles County Museum of Art (LACMA). ${ }^{10}$ In this essay, Kozloff describes how the poetic conditions of any artwork are manifest in how the object has recorded the process by which it was made, or through its ability to evoke the presence of the human body in action or in its potential for change.

In order to explore what form this Poetics of Softness might manifest within architecture, this study will focus on two of my most recent speculative design research projects, the Measure House and Bang Bang House. Both projects exist here in this article as a series of textual descriptions and drawings, proposing structures which are sited in distinct locations where the ecology, weather or landscape is experiencing, or is predicted to experience, the effects of climate change in the twenty-first century. The speculative architecture presented here, allows for a more expansive exploration and discourse on architecture's poetic attributes and the political and environmental significance of these attributes. Where traditional forms of architectural practice are often controlled and augmented by the heterogeneous conditions of regulations, economics and the desires of clients, speculative architecture allows the latent potentiality of the architect 
and building's occupant to explore an alternative state for society, design and the environment.

To help discuss, define and expand upon how these projects embody this specific poetic quality, the essay will situate them in relation to the innovative cross-disciplinary responses to the environment encompassing Land Art, Process Art, Architecture, and Performance Art which emerged in the 1960s and 1970s; work that was being produced around the time Kozloff himself was writing. These works embody some of the richest engagements with the environment seen in recent times, engagements that can guide our architectural response today. Within this context, the essay will also set out an innovative model for utilising the ideas and practices of performance and performativity associated with these practices into architecture and architectural discourse. Just as they emphasise the importance and significance of the body and its actions, so this new model seeks to celebrates one's physical and temporal experience as opposed to one that is distant and mediated by mechanical processes and reason.

The essay will reflect on the cross disciplinary practices of the 1960s and 1970s represented in the works produced by Artist Robert Morris and Architects Gianni Pettena and Raimund Abraham. Where Morris acts as a conduit to directly interpret and represent the ideas of Kozloff, the work of Pettena and Abraham, although existing in a kind of interdisciplinary polyphony, manifest these ideas through the discipline of architecture of which these two were key protagonists.

The explorations in the essay will be split into two sections. The first of these will set out to investigate methodologies of design that embody Kozloff's notion of softness. The second will explore how this poetic exists in the way forms, spaces and materials are altered through their relationship to specific environmental and celestial conditions, reflecting the performative nature of design. 


\section{Part One: Softness in Actions}

\section{A Poetic through the process of making and designing}

The Measure House (Figs. 1 - 3) is a structure proposed to be located in the decommissioned granite quarry, Dean Quarry, located on the Lizard Peninsula situated on the west coast of southern Cornwall (Fig. 4). The maritime climate of this coastal region in the south-westerly county of the UK is dominated by the sea and moderated by the Gulf Stream, a warm current that circles up from the middle of the Atlantic northwards to the Arctic. This means the area has an average temperature two degrees higher than those further inland. ${ }^{11}$

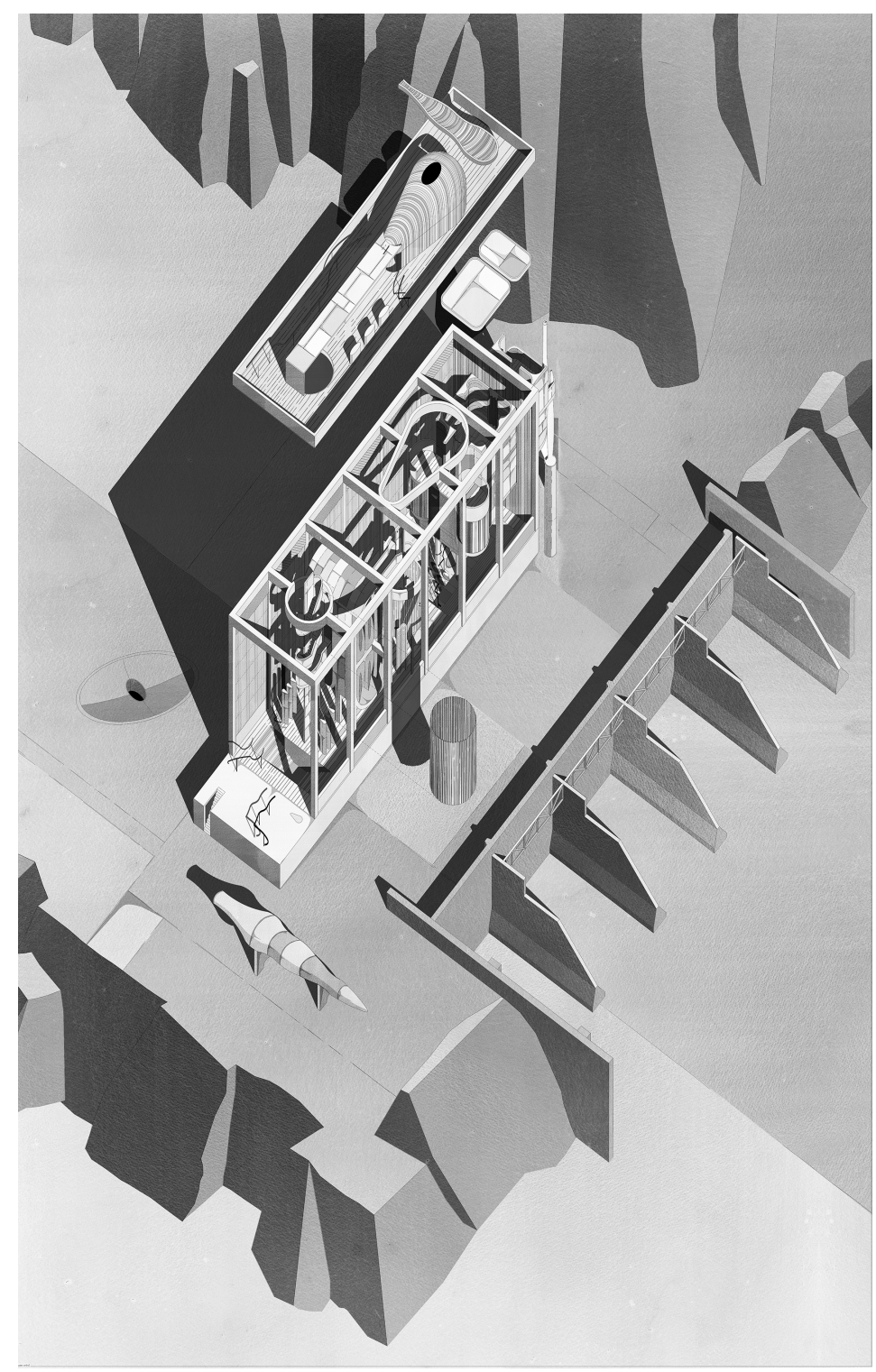

Fig. 1: Author, Measure House, Lizard peninsula, Cornwall: exploded isometric, 2017. 

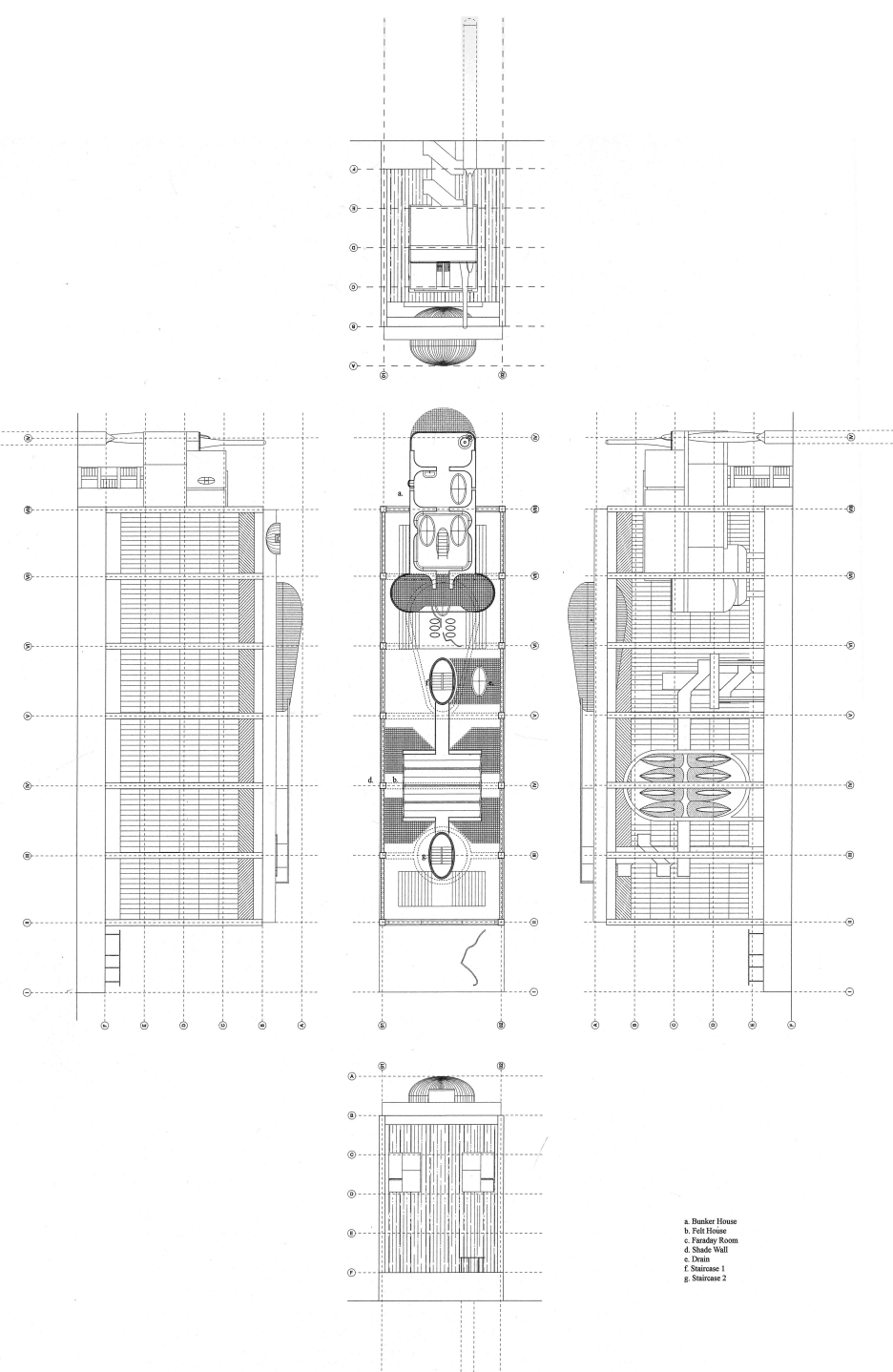

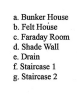

Fig. 2: Author, Measure House, Lizard peninsula, Cornwall: plans and elevations, (2017).
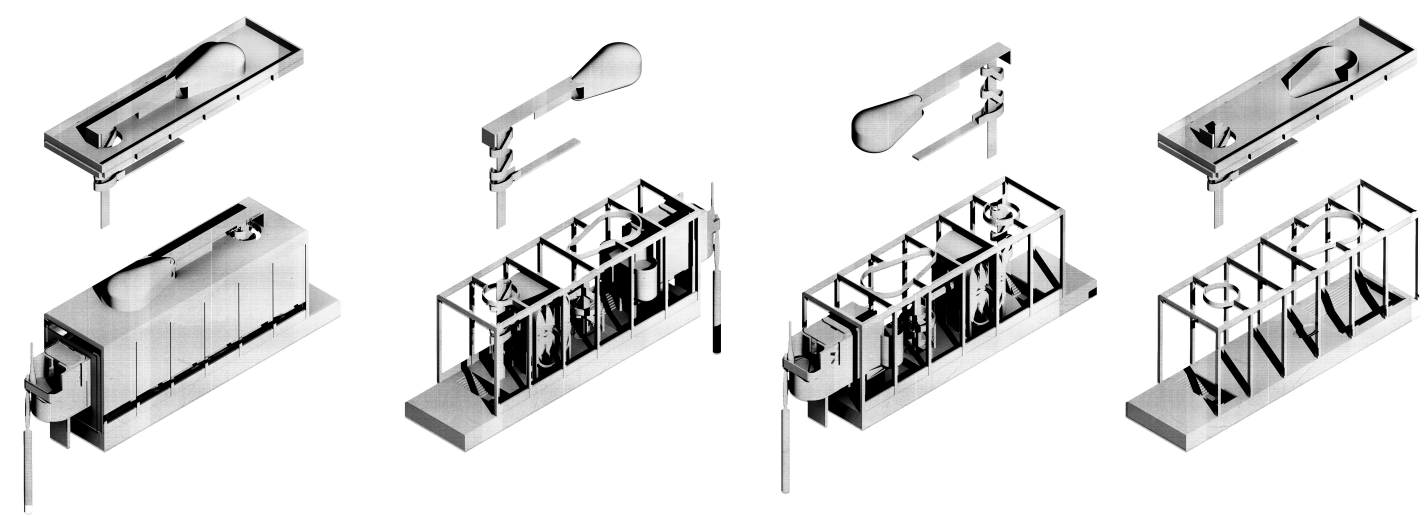

Fig. 3: Author, Measure House, Lizard peninsula, Cornwall: isometric, 2017. 


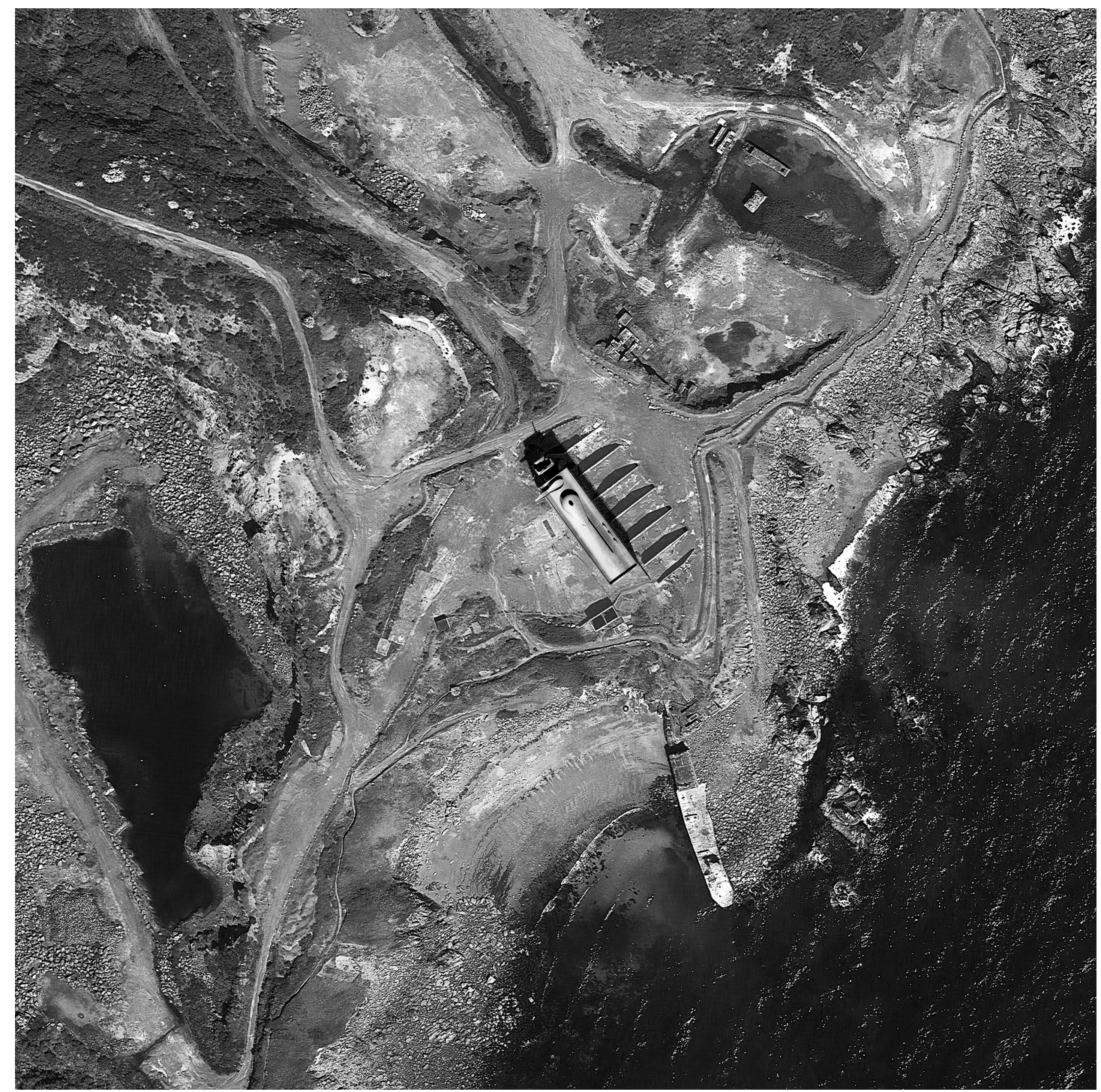

Fig. 4: Author, Measure House, Lizard peninsula, Cornwall: site plan, 2017.

As global temperatures rise in the manner they are predicted to, ${ }^{12}$ and the ice in the North Pole starts to melt, the effect on the current, and the temperatures the Gulf Stream maintains, could be dramatic. With the increase of fresh water from melting glaciers falling into the Atlantic, the current's cycle will be disrupted and slowed. ${ }^{13}$ This change could intensify temperatures across northern Europe and the west coast of England and Cornwall, which may mean that those inhabiting these regions experience hotter summers and colder winters, and generally more unstable weather patterns. ${ }^{14}$

The Bang Bang House (Fig. 5) is located in another region of England off the Coast of Canvey Island, in Essex, and is nuzzled within the abandoned jetties of the Coryton Refinery in Holehaven Creek, which is part of the Thames 
Estuary (Fig. 6). The series of large-scale metal pontoons on which it sits allow the structure to float at high tide, and rest evenly on the mud at low tide. It is moored not by anchor, but instead housed within a pen of metal fencing and steel tubular foundation piles driven deep into the Canvey mud flats. In addition to the main house there is an auxiliary accommodation called the Reed House (Fig. 7) ${ }^{15}$ which is used primarily in the summer as a retreat to the Canvey mud flats. Access to this part of the house is via a series of sediment banks that protrude from the Thames Estuary. These beach-like mud banks in the Reed House are formed by large sediment nets anchored and placed in the water to slow the current, allowing heavier silt to settle on the riverbed and build up over time, leading to the formation of a new raised access route to and from the main house. The main accommodation of the Reed House is formed from a reeds enclosure that raises those inhabiting the structure away from the mud flats when the tide is lowest. 


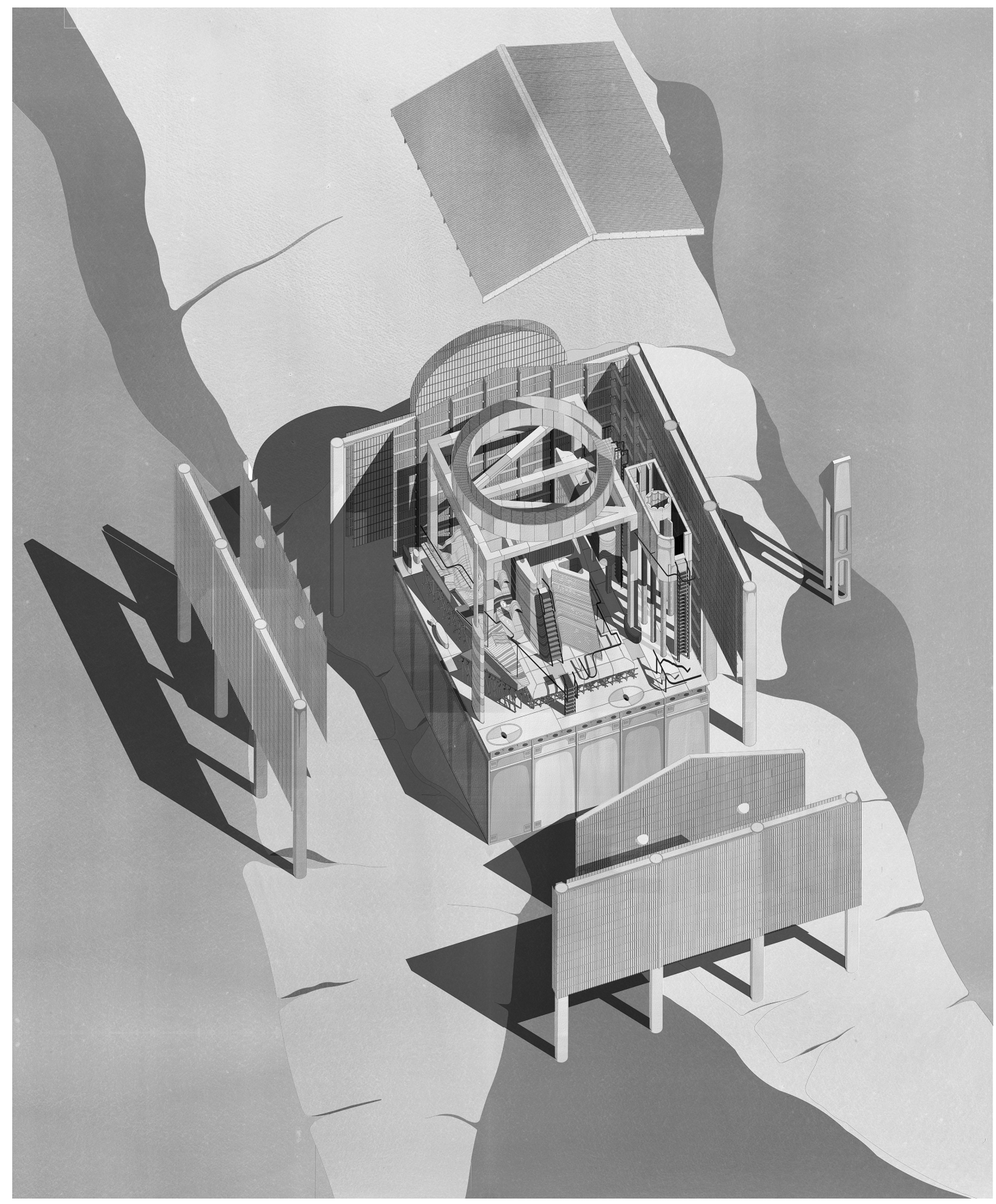

Fig. 5: Author, Bang Bang House, Holehaven Creek, Thames Estuary: exploded isometric, 2017. 


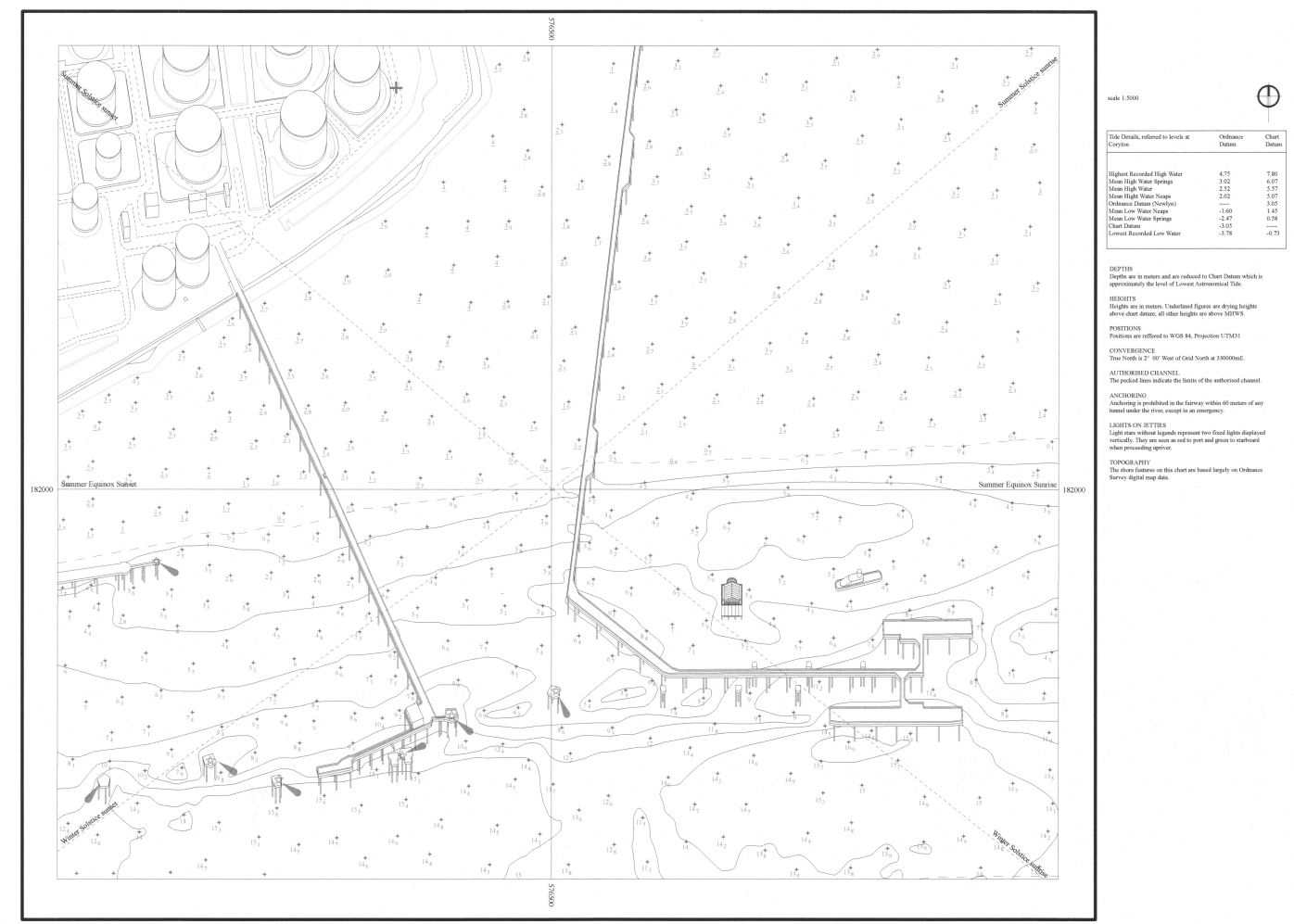

Fig. 6: Author, Bang Bang House, Holehaven Creek, Thames Estuary: site isometric, 2017

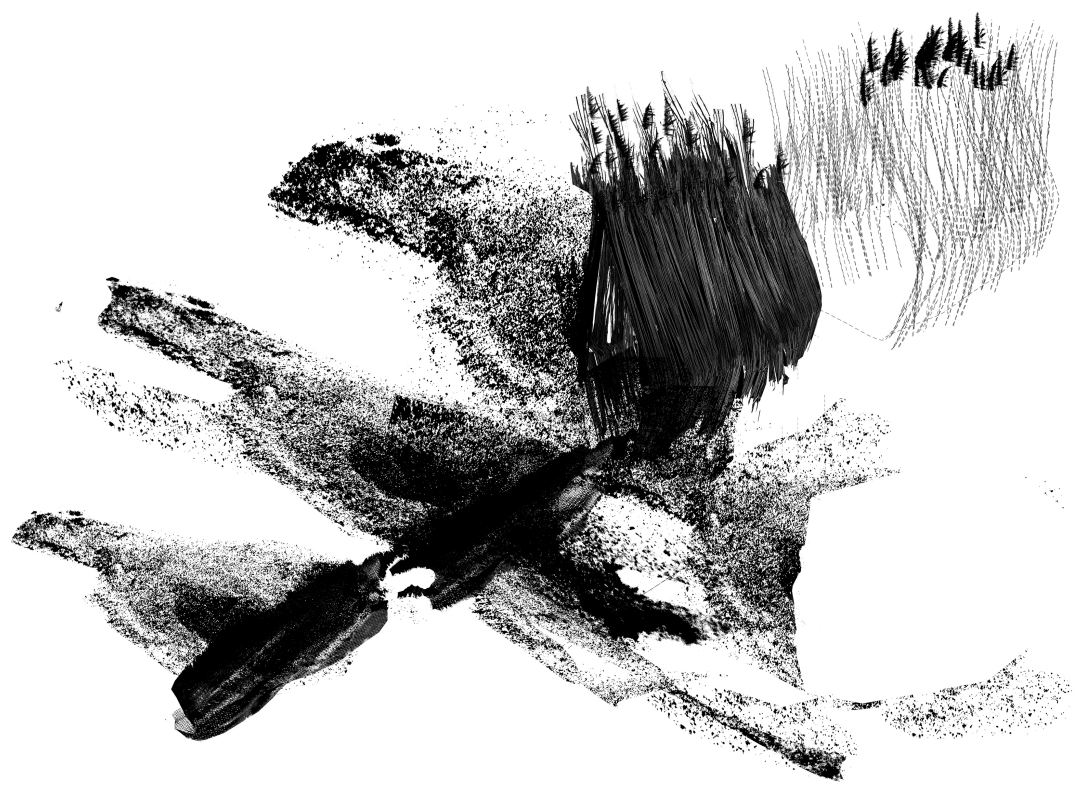

Fig. 7: Author, Isometric Reed House with Sediment Nets and Sediment Banks, Holehaven Creek, Thames Estuary: isometric, (2004 - 2017).

Although both buildings have specific material, formal and spatial responses to their individual environments, something that will be discussed later in the essay, I would first like to introduce a specific design methodology that can be 
attributed across the formation of both projects. A poetic methodology which can also be understood as pertaining to actions that are performative.

This performative design methodology was initiated through the construction of a series of two-dimensional drawings existing as a set of patterns formed from a variety of grids and dots. These drawings were then dragged across the surface of a photo-copier or scanner while it was in the process of scanning to produce multiple distorted versions of the initial grid. (Fig. 8) This was completed several times with each drawing using different rates of drag across the scanner to ascertain different results. The effect that is created, patterns that look something akin to motion blur, are a real-time record of the action of the drag. 

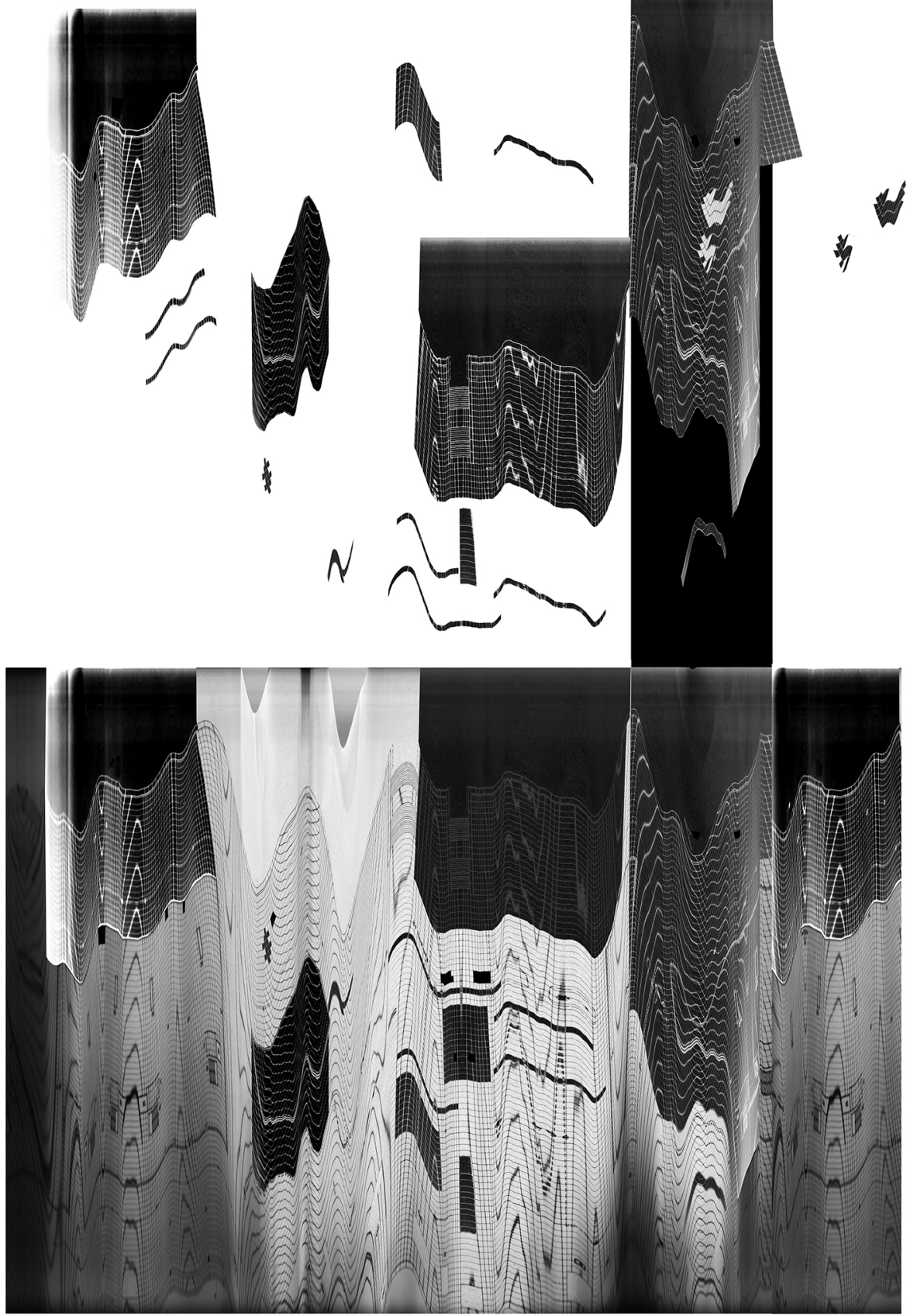

Fig. 8: Author, Wobble Drawing 009 with element extractions, 2017.

Once these actions or drags, named the Wobble Drawings, have been completed the images are laid out in order to assess the final results of the process. Through this assessment certain images are selected and specific 
shapes and patterns extracted, both digitally in Photoshop and manually using a scalpel. These shapes and patterns are then recomposed into elements that could form potential architectural features. These forms were then used directly in the formation of the undulating concrete surfaces and floors of the Bang Bang House (Fig. 9) as well as in the exterior shapes of several of the internal rooms or enclosure. Extracted forms from these drawings were also used in defining the sculptural forms dotted around the Measure House and the floor surface of its Sanctuary Space (Figs. 10 - 11), a space designated for reflection and located on the roof of the structure. In all instances, the translation of the scan into architectural elements creates a complex formal language, existing as a sculptural record and manifestation of the original physical action of the scan.

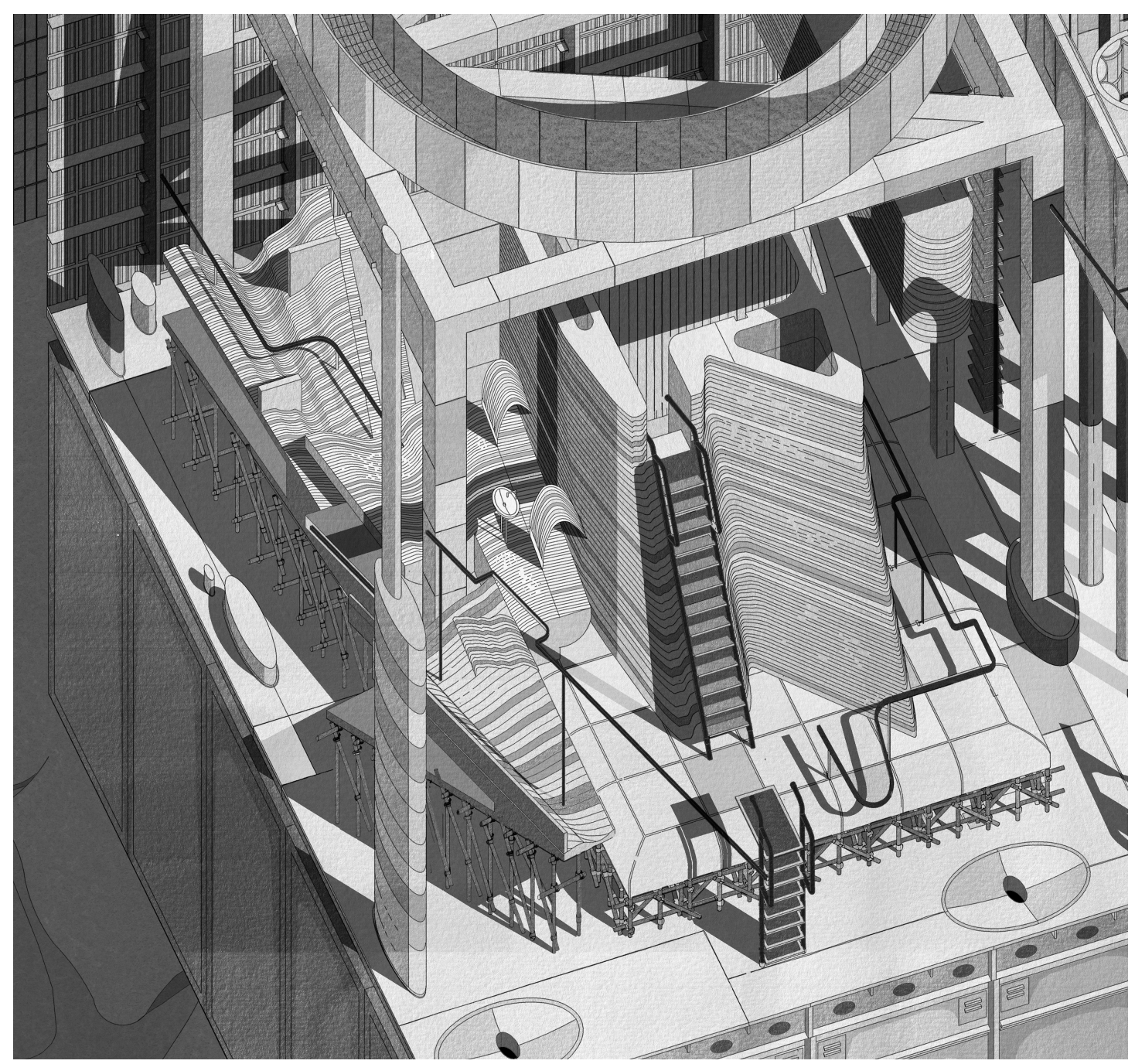

Fig. 9: Author, Detail Bang Bang House, Holehaven Creek, Thames Estuary: isometric, 2017. 


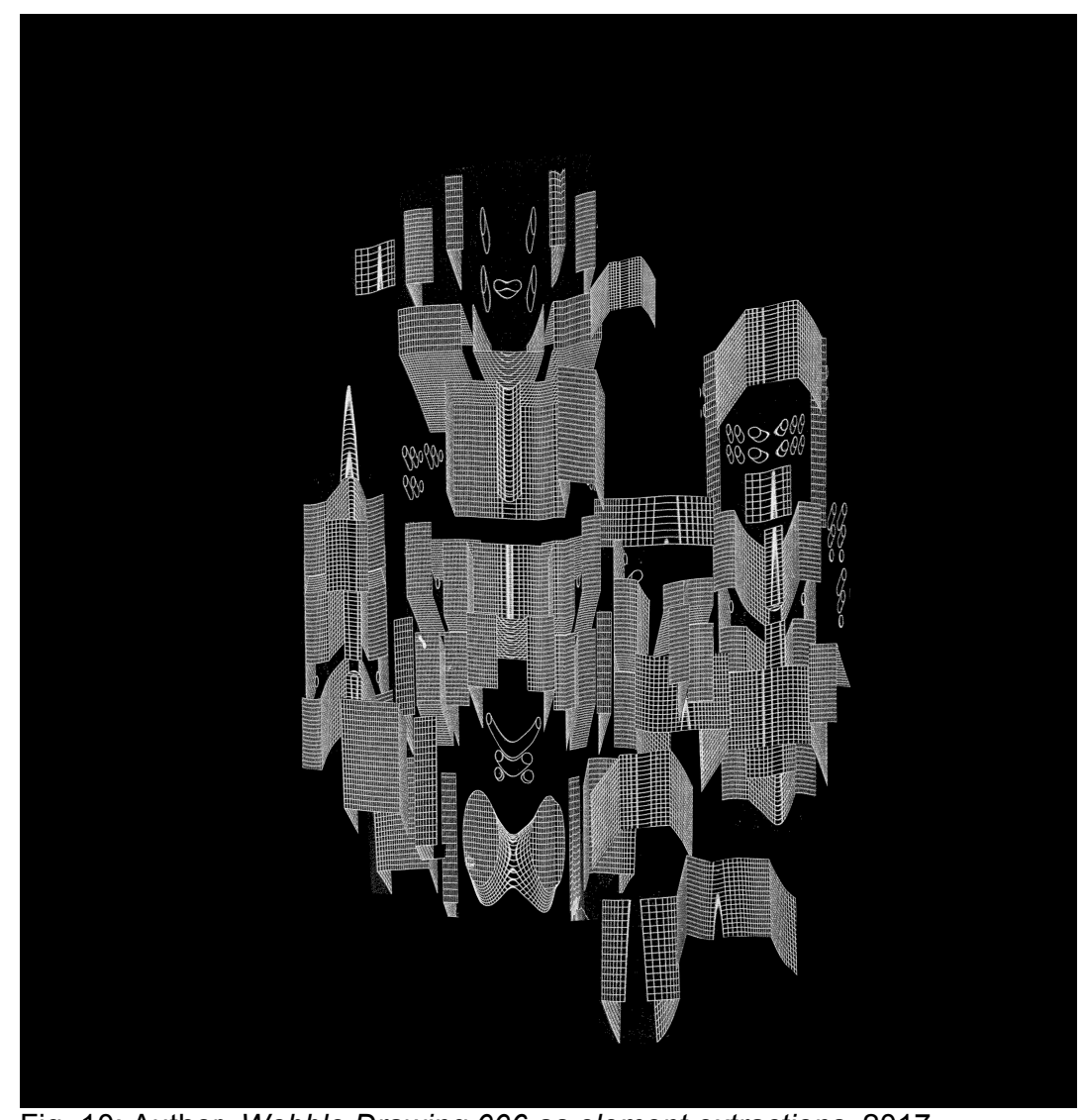

Fig. 10: Author, Wobble Drawing 006 as element extractions, 2017. 


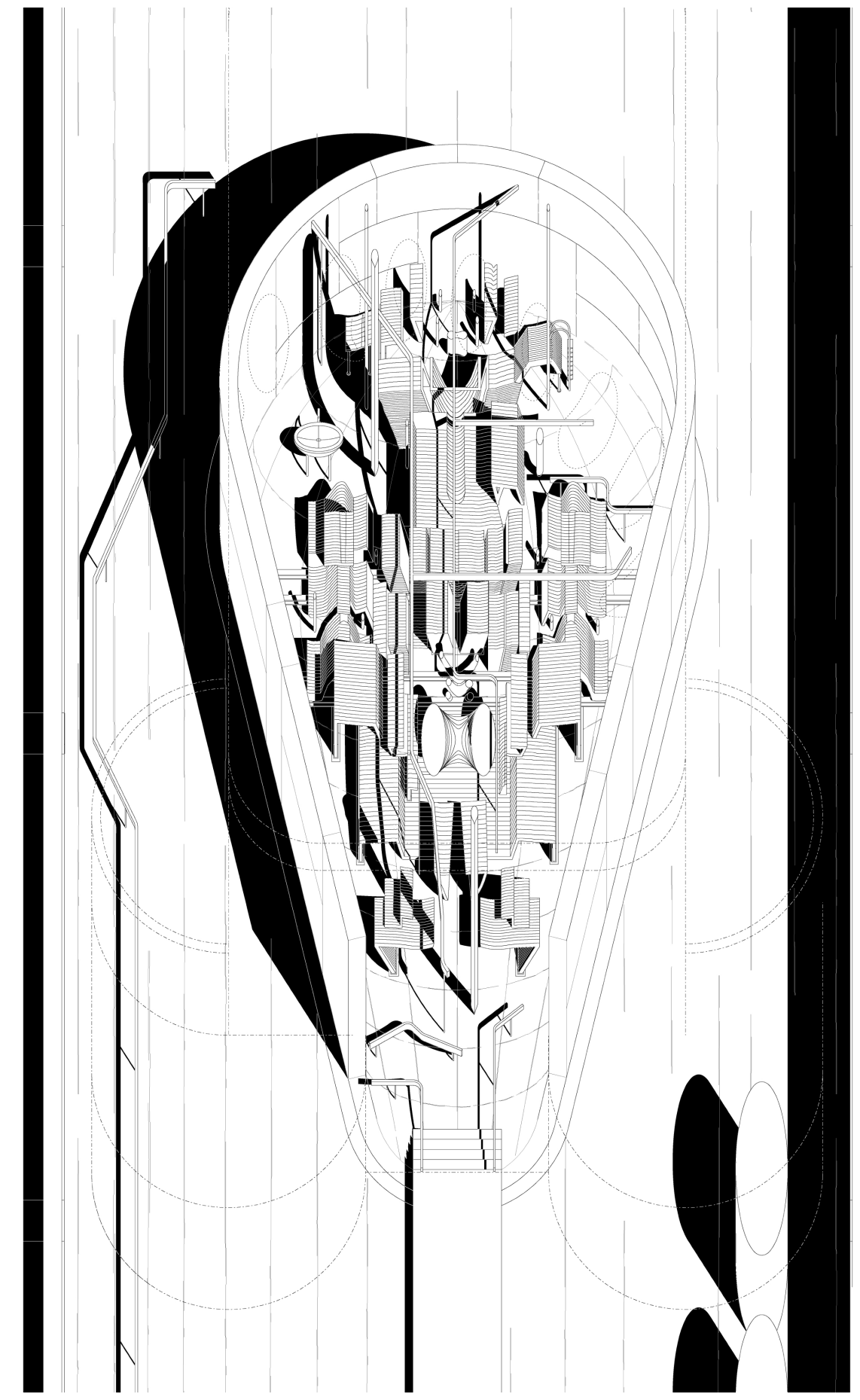

Fig. 11: Author, Isometric Interior of Measure House Sanctuary Space, Lizard peninsula, Cornwall: exploded isometric, 2017.

This process resonates with certain works by artist Robert Morris, in particular his series of felt pieces, started in the early 1960s. To create these works he would lay individual sheets of the material horizontally on the ground before cutting patterns, lines or grids into them with a Stanley knife. ${ }^{16}$ The sheets of felt were then hung vertically on the wall. The action of gravity working in conjunction with the patterns cut into the felt sheets determined the way the 
material slumped to rest in place and thus defined the finished sculptural composition. This performativity is also manifest in his Blind Time Series I (1973) (Fig. 12) and Light-Codex-Artifacts I (Aquarius) (1974) which are drawings he created when blindfolded, using his hands to move and manipulate powdered graphite, Vaseline and pencil on paper while following a series of set criteria such as grids or written rules.

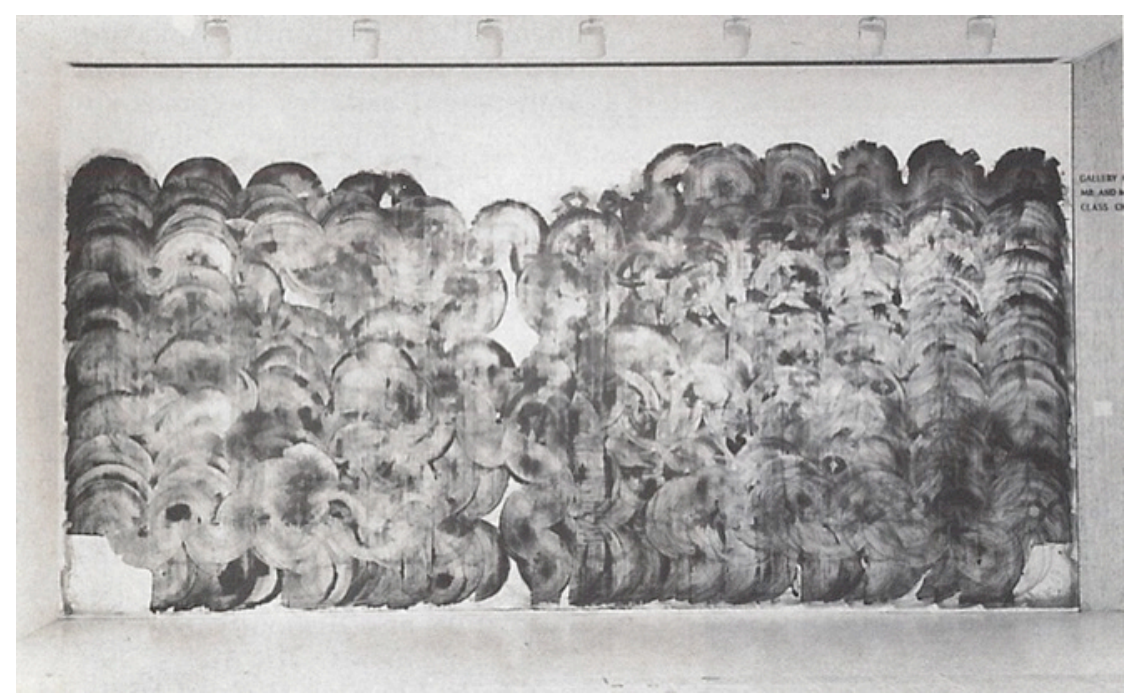

Fig. 12: Robert Morris, Blind Time I (1976). Copyright Courtesy of the Artist and Leo Castilli Gallery. ${ }^{*}$ Copyright to be confirmed.

Morris understood works of this type as Process Art which, as art historian Suzaan Boettger states, was 'a manifestation of a physical procedure - the artist's manipulation of matter in relation to both the literal material and to immediate spatial constraints'. ${ }^{17}$ This emphasis on actions, materials and artistic process also had strategic meaning for Morris. In an article in Art Forum in 1970 he pointed out that

the entire enterprise of art making provides the ground for finding the limits and possibilities of certain kinds of behaviour and that this behaviour of production itself is distinct [...] This extended profile is composed of a complex of interactions involving factors of bodily possibility, the nature of materials and physical laws. ${ }^{18}$

It was also an analogy for his desire for a greater physical awareness of his surroundings: 'As ends and means are more unified, as process becomes 
part of the work instead of prior to it, one is enabled to engage more directly with the world in art making. ${ }^{19}$ It is an idea that is reinforced by historian Paul Schimmel who states in the catalogue to the 1998 LACMA exhibition 'Out of Actions: Between Performance and the Object 1949-1979', that artists working during the 1960s and 1970s were operating within a context that acted in response to the atrocities of the second world war. A condition that saw a change of consciousness in the world at large: 'The possibility of global annihilation had made human beings more aware than ever before of the fragility of creation, subject as it was to forces of destruction of unprecedented magnitude. In this regard, it also made them more cognizant of the primacy of the act. ${ }^{20}$ For Schimmel, the human act or action of pushing the button to launch the nuclear bomb, or burning fossil fuels, is directly linked to the shift of emphasis in the production of art, where the act of making, drawing, performing and painting was fore fronted with new meaning, changing the aesthetic of the final artwork.

Critic Rosalind Kraus acknowledges this practice as having its roots in Morris having worked with choreographers such as those associated with the Judson Dance Theater, ${ }^{21}$ a collective of dancers, composers and visual artists who performed at the Judson Memorial Church in Manhattan, challenging traditional modes of art production such as painting and sculpture as the dominant mediums. In Krauss' essay 'The Mind Body Problem: Robert Morris in Series', written for the catalogue for Morris' retrospective at the Museum of Modern Art (MoMA), New York, in 1994, she states that:

Making the mark in sympathy with the nature of one's tool had, of course, been inherent in the Judson dancers' manipulation of bizarrely commonplace props in their search for an 'aesthetics of task performance'. And so the notion of process art as a form of performance came naturally to Morris. ${ }^{22}$

The practice of making work is thus a performance with our physical environment and with the very essence of matter. 
In Morris' actions in these works, and with them the Wobble Drawings, we see practices that fit within the parameters set out by Max Kozloff's definition of a 'Poetics of Softness'. Writing during the period that Morris was coming to fruition during the late 1960s and 1970s, Kozloff suggests that the poetic is a condition that exists in the aesthetic effects, primarily in sculpture, of the absence of defined hard boundaries. He describes how it is a condition that primarily exists in such works as Claus Oldenburg's fabric sculptures and in Morris' felt works, where there is the celebration of a sense of indeterminacy, a condition that is enhanced by their flexibility and their unstable nature. For Kozloff, 'softness' exists 'in the literal sense of easily yielding to physical pressure. A soft thing can be poked, molded, squeezed, scrunched. In a word, its surface is elastic, and its densities are scandalously re-arrangeable. ${ }^{23}$ It was also a condition that not only referred to the nature of the materials being used by the artists but also in the way the works were made, including the artists' physical action of making, which he states 'will unavoidably invoke the human'. ${ }^{24}$ This condition for Kozloff was singularly about a poetic but also a direct destabilisation of the rigidity, structural stability and determinacy of Modernist sculpture that exists in 'an incurably alert production, stressing fixity, endurance, and power - all that man himself cannot maintain except in intermittent defiance of gravity'. ${ }^{25}$ In contrast, soft sculpture 'mimes a kind of surrender to the natural condition that pulls bodies down'. ${ }^{26}$

\section{Soft Actions in Architecture}

Within the context of architectural discourse and practice at the time that Morris was working, particularly in the work of both Raimund Abraham and Gianni Pettena, we also find emphasis on the process of developing works directly from the actions of the human body. A process which we have seen can be defined as manifesting a poetics of softness.

Within the work of Raimund Abraham, we see this resonance in the way he describes his distinct methodologies of drawing; a process where he developed specific techniques using coloured pencil to build up tone and texture on paper. It was a technique that insured that the final drawing revealed how they were created, each visible mark contributing to the whole. 
It was also necessary as a means to define his particular view of how architecture should relate to the sites in which it was intended to exist. Discussing his drawing process in a lecture given in Vienna in 1986, he stated: 'The principle of drawing reveals the origin of architecture [...] For me the piece of paper is the space and the pencil the tool with which to intervene and shape. ${ }^{27}$ This is a point he elaborates later in the lecture, linking the physical action of drawing to architecture's physical engagement with any site through the process of construction, 'to the place of interference, to the place where the earth is touched and the scratch eventually becomes the actual drawing. This is how physiological language turns into geometrical language. ${ }^{28}$

This was a move that was still echoed in his writing a few years later. In a poetic text titled 'In Anticipation of Architecture', he wrote:

Born into the landscape. To touch it, to smell it, to let the eyes graze over it, to let the eyes dig into it, to scratch signs into the earth, to excavate cavities, to pile up mounds, to bury the entire body in the earth, to measure with groping steps, to feel space, to draw scales and to engrave them eternally into stone. ${ }^{29}$

Abraham's statement is important as it unites his particular interest in drawing and mark-making with our experience and inhabitation of landscape. It also suggests a move whereby the physical actions of the body eternally digging, interacting and re-forming the material of the earth, without the technology of tools, provides us with a model in which we might experience the soft poetic through the instinctual desire to create drawings and to create dwellings.

This connection between mark making, the construction of environments to occupy, and ways to re-experience the landscape, resonates with the formations of the undulated surfaces in the Bang Bang House and Measure House that were derived from the dragged wobble drawings. The surfaces created offer places for occupants to sit, lie and rest, reminiscent of the landscapes the houses inhabit - the undulated wave-like forms of mud flats outside the Bang Bang House and the surfaces of cut and shattered rock of 
the Dean Quarry surrounding Measure House, mirroring Abraham's words to excavate cavities, to feel space, to draw scales.

In the methodologies defined in the first part of this article that outline the process through which Morris and Abraham made several of their drawings and works, we see resonances with the Wobble Drawings and with them certain formal logics that exist in the Measure House and Bang Bang House. Principally what links them is the desire to celebrate the tactility, immediacy and indeterminacy of a physical action, whether represented in the making of an artwork, or in its record or documentation. These actions - often set within certain clear parameters, whether by the materials being used, or by the rules to determine the limits to what is allowed to make them - can be understood as a form of performance. A performance that insures that the images and forms created record the presence of a human body in motion. It is also a performance that seeks to draw the person making or experiencing the work into the poetic, closer to the physical world of matter and the environment.

\section{Part 2: Soft Bodies and Soft Structures}

\section{Environmental Barometer}

As well as manifesting a poetics of softness in the process of design and the effects of this process on the form of The Measure House and Bang Bang House, we can also read this poetic in the way the projects seek to redress the physical experience of the body. This condition aims to reframe the way we would encounter the direct environment in which the projects are proposed to be sited, as well as raise awareness of and respond to changes at a global and ecological scale. Changes that could include the collapse of the Gulf Stream or the rise in unpredictable tidal behaviours across the North Sea.

In the Measure House this is manifest in a series of ways. Firstly the building is designed to enhance the understanding of the actions of celestial events. This occurs in the way the building frames and emphasises the movement of 
sunlight, where the behaviour of shadows is paramount to the occupants' experience of the space. (Fig. 13) In the main atrium, angled to face the morning sun, the shadow of the large gridded frame structure of the building's outer shell fluctuates as it moves from east to west. This effect is further exaggerated by the grandness of this central space and the placement of a shield wall on the south-eastern face which acts as a canvas to catch the light and shadow. The experience of sunlight and shadow within this main space, as the sun appears and disappears behind clouds, creates a constant state of flux in the building; a flux that exists as layers of different material and shadowed geometries are overlaid from day-to-day and season-to-season. We can see this fluctuation demonstrated in Fig. 14.1 and Fig. 14.2 which show plan views of light conditions that effect the building at different times of the day and year, including with different cloud cover. ${ }^{30}$

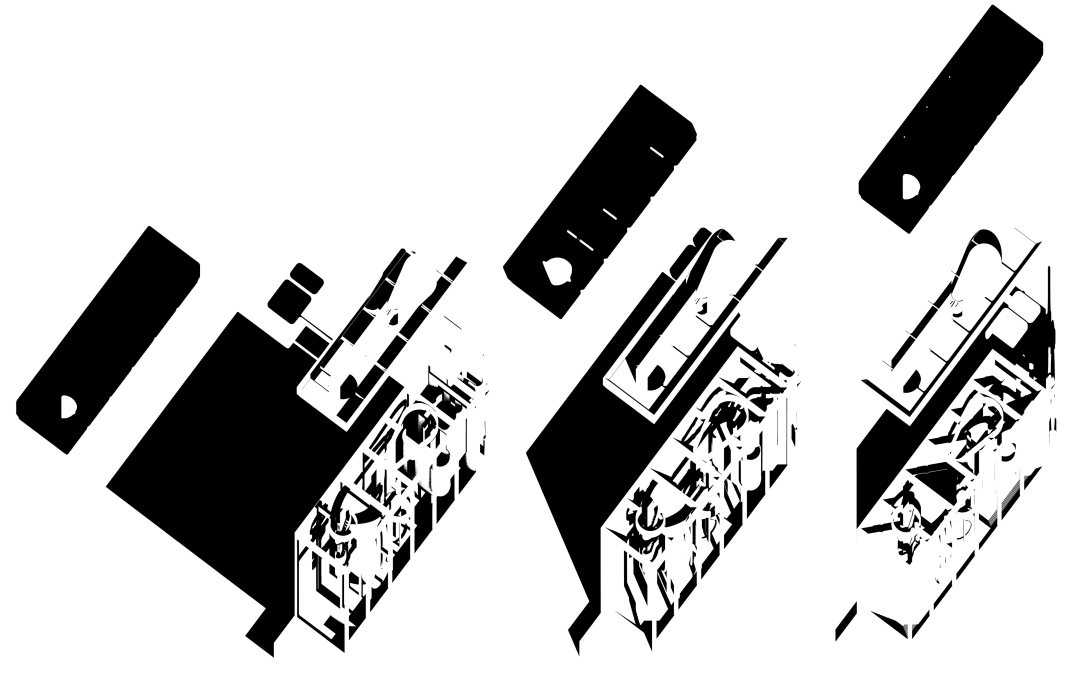

Fig. 13: Author, Movement of Shadows in Measure House, Lizard peninsula, Cornwall: isometric, 2017. 


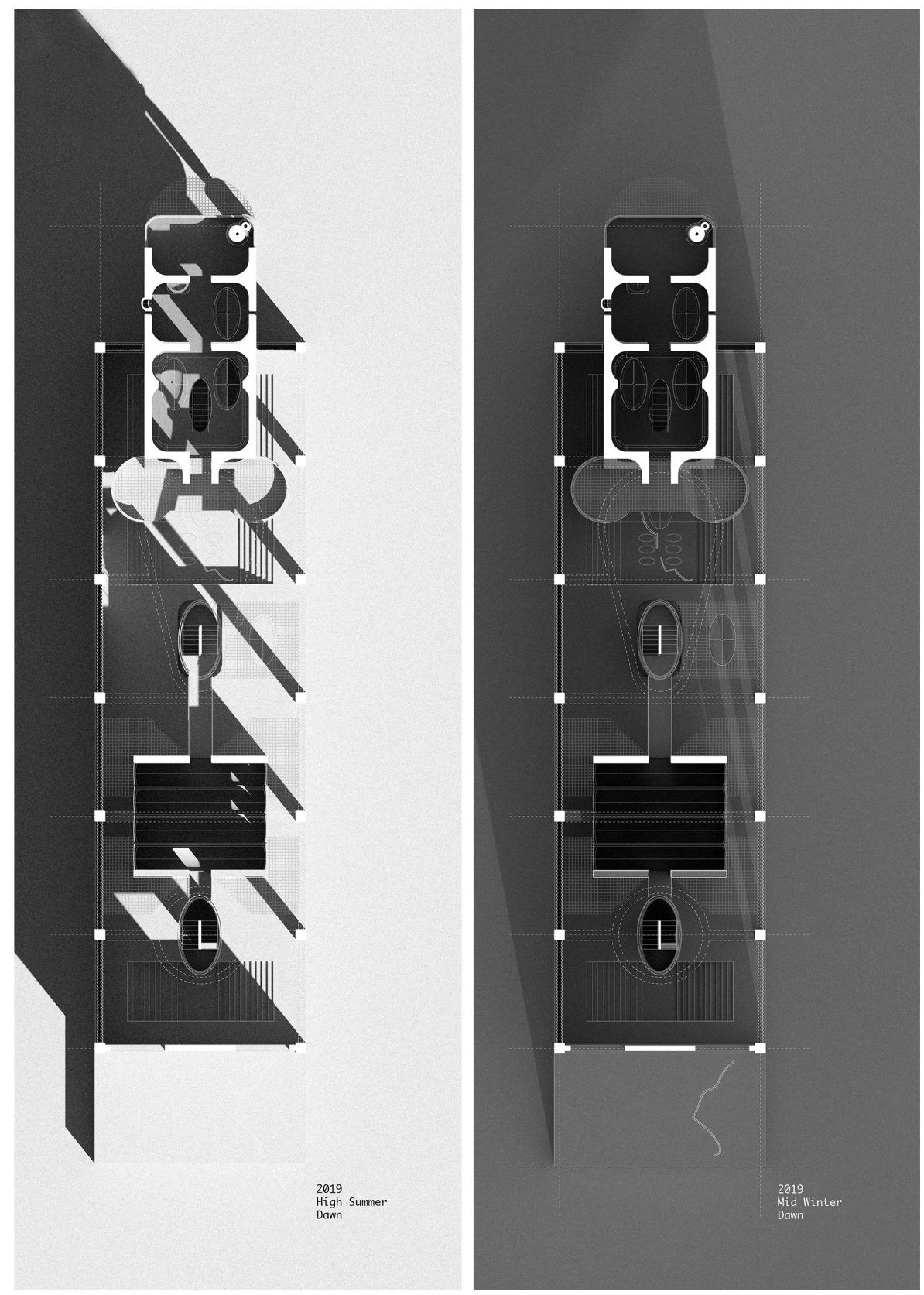



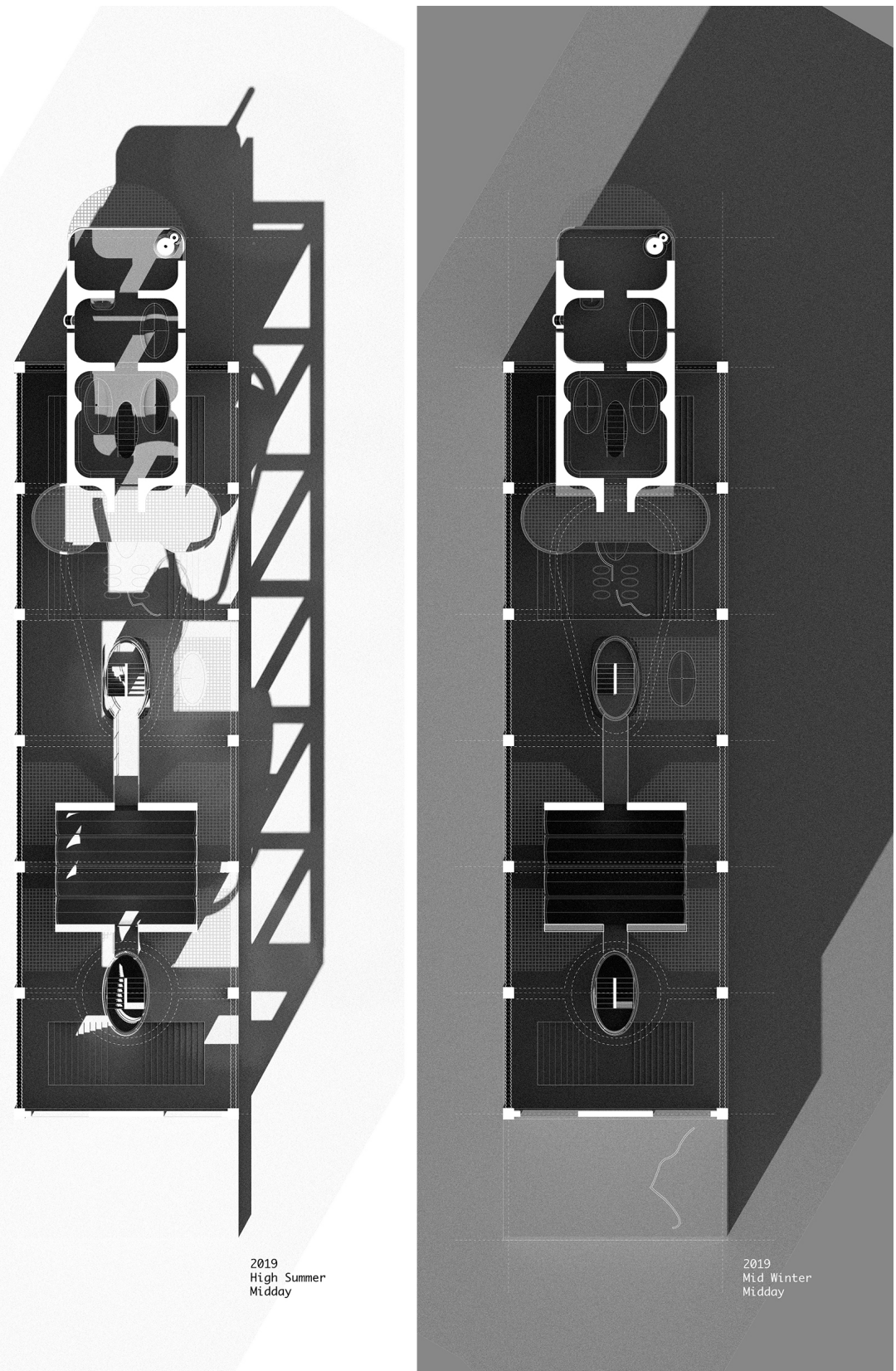

Fig. 14.1: Author, Movement of Shadows in Measure House, Lizard peninsula, Cornwall: Plans, 2017. From left to right: High Summer Dawn, 2019 - Mid Winter Dawn, 2019.

Fig. 14.2: Author, Movement of Shadows in Measure House, Lizard peninsula, Cornwall: Plans, 2017. From left to right: High Summer at Midday, 2019 - Mid Winter at Midday, 2019.

In contrast to the main atrium, the Sanctuary Space on the roof of the Measure House controls the actions of the sun more directly. Here the movement of the sun is not there to create an intense overlay of light and shadow and is instead a point for simple reflection. The cavern-like interior has no windows and instead draws in light from an oculus in the roof, the 
shifting sun slowly mapping the movement of the earth across the floor and internal walls, as in Rome's Parthenon.

In Bang Bang House, celestial movements are represented through the building's alliance with the rise and fall of the tide, which is controlled by the gravitational pull of the moon on the earth. The presence of these forces is primarily experienced when the tide allows the structure to float and as waves from passing ships in the estuary wash under and around the building. As it is pushed and pulled from side to side within its metal pen by the currents and wind, there is a continuous metal clanging of the structure of the building against the pen in which it is stationed, a constant reminder of its situation within a complex system of weather and tides. When the sound of the banging becomes too intense, those occupying the building are able to use certain rooms that have sound insulation and padded walls to muffle the perpetual noise. The structure only becomes silent again at low tide, when it rests on the mud flats. This undulation in sound, at both the scale of the building and the scale of the landscape, is represented in the graph in Fig. 15. The increases in sound within the structure at the points at which the current is strongest - as the tide shifts from rising to falling, a time when the forces experienced in the river are greatest - are clearly illustrated. Occupying a site primarily submerged at high tide, the experience of celestial movements in Reed House, the Bang Bang House's auxiliary accommodation, is indicated as levels of sediment slowly build up with the emergence of each tide. Anyone visiting the structure from week to week would witness the sediment brought with each tidal surge increase over the surface of the structure. 


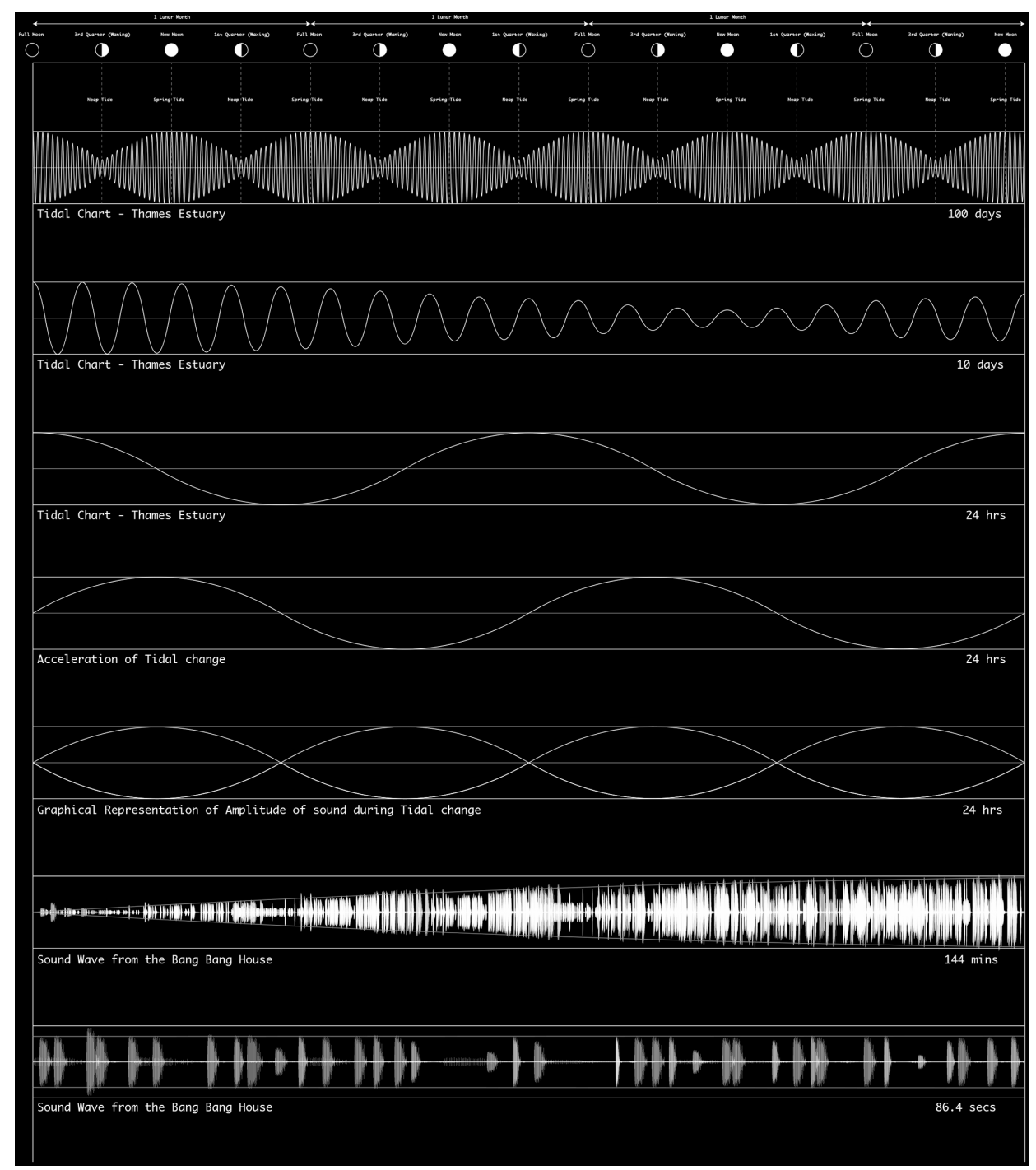

Fig. 15: Author, Bang Bang House, Holehaven Creek, Thames Estuary, 2017.

Sound graph shows relationship of the banging in the house caused by the strength of the tidal currents at different times of the day and month. Graph shows the relationship of this change in tide to the effect this would have on the sound the house makes at each minute.

All of these material and ephemeral actions and events are in part also barometric warnings of climate alterations due to global warming. If the shadows that are so central to the occupants' experience of the Measure House grow in strength during the year or are more present than normal in winter months, this would signal an increased amount of sun in and around the Cornish coast. A possible signal to the collapse of the Gulf Stream as cloud cover, prominent in the colder months, would be burnt off and temperatures increase with the rise in heat transference that would occur in this scenario. In Bang Bang House, an escalation in the intensity and length of time the banging occurs each day would signal an increase in tidal heights or flooding of the River Thames which would mean the tide would not retreat as 
expected. In the Reed House, raised levels of sediment build-up would also be an indication of a surge in flooding events. The rooms and materials of each building thus become mechanisms that allow an experience that exists in a specific space or moment to be viewed as a signifier of a universal change. Embodying and surrendering to the alterations in the ecologies of a particular site, the projects express the poetic by reflecting the large scale and fluctuating systems of global ecologies and the broader effects of climate change.

These conditions of framing celestial movements and emphasising the physical transversal of the building are also tropes presented in Robert Morris' large scale land art work, Observatory, created in 1971. (Fig. 16) Originally constructed in Velsen in the Netherlands, but later moved to Lelystad near Amsterdam, Observatory consisted of two concentric inhabitable spaces, one inside the other. Within these earthen ramparts, a series of openings, each aligned to frame certain key celestial events such as the summer and winter solstices, referenced prehistoric sites used for the observation of the sun and the planets, such as Stonehenge in England. It was an architectural-scaled device for witnessing the larger processes that govern our experience of the world which was only understood through circumventing its enclosures; one had to physical move through and over to experience it.

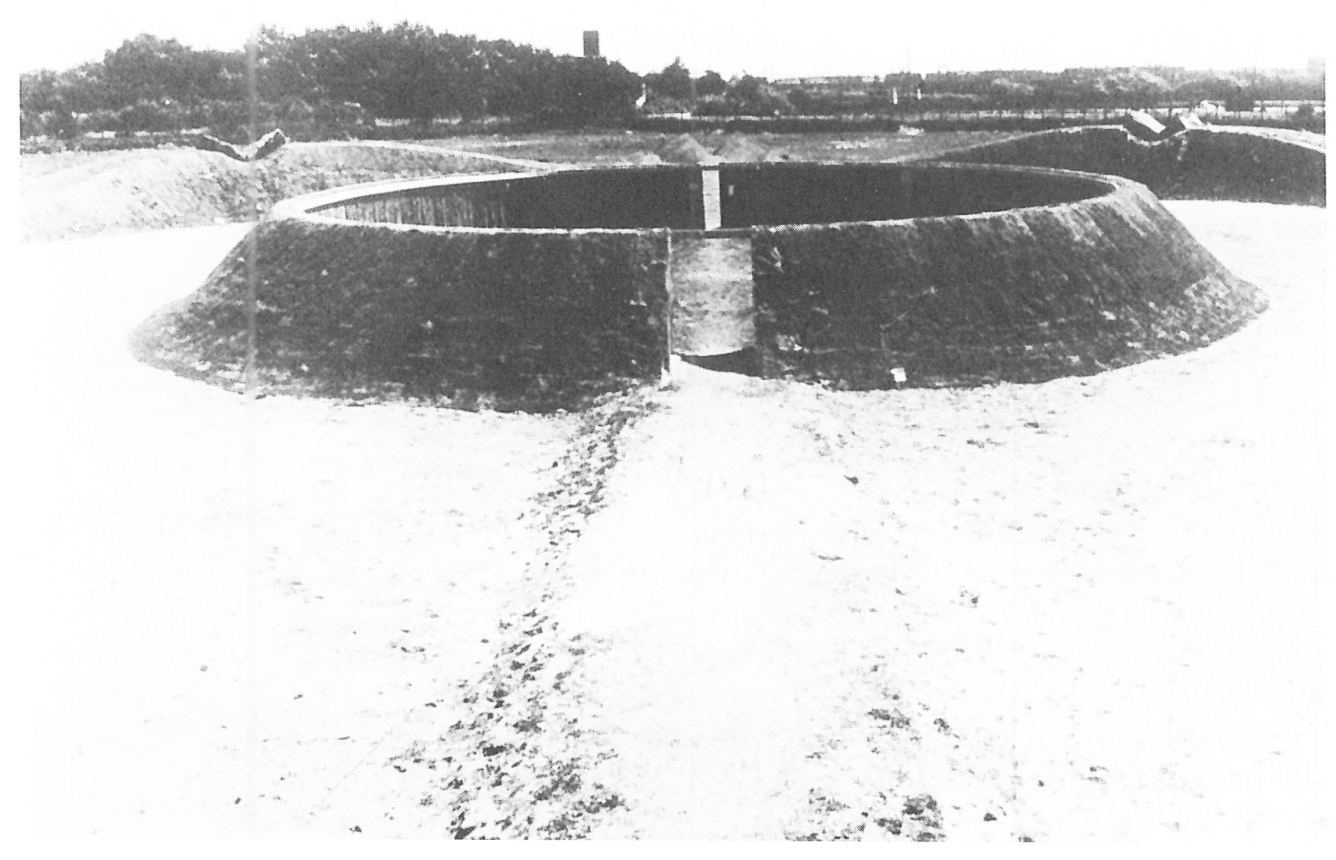


Fig. 16: Robert Morris, Observatory (1971). Copyright Courtesy of Leo Castilli Gallery. *Copyright to be confirmed.

Rosalind Kraus sees Observatory, in its aim to engage the movement of the body with the movement of the sun and moon, to also be linked conceptually to Morris' process-driven work of the late 1960s. Writing again in her text the 'Mind Body Problem' she states that it existed as 'a massive project through which to think and to experience this culturally ancient notion of marking, which is to say, of entering into a text that one has not oneself written, and that will continue to be produced to the end of solar time'. ${ }^{31}$ Here the marks were not just those of the artist's body, or of those who circumvented it, but were instead generated by the movement of the earth and the sun, conditions that also control our climate.

Alongside a desire to express the experience of celestial movements, Morris was also attempting, with works such as Observatory, to strike a polemic which sought to comment on a relationship that humans were fostering in the late 1960s and early 1970s; a relationship towards the environment that he saw as problematic. Similar in ambition to the aims of the Measure House and Bang Bang House, Morris was trying to embed his work with the observation that society's increasing reliance on technology, and a reliance on logical or numerical thinking during this time, was becoming a problem. In his article 'Notes on Sculpture Part 4: Beyond Objects' for Artforum in 1969, he asserted: 'An advanced, technological, urban environment is a totally manufactured one. Interaction with the environment tends more and more toward information processing in one form or another and away from interactions involving transformations of matter. ${ }^{32}$ Reiterated in his essay 'Notes on Art as/and Land Reclamation' from a decade later, ${ }^{33}$ Morris lamented the use of natural resources in creating structures such as dams, coal mines and radio telescope arrays:

All great monuments celebrate the leading faith of the age - or, in retrospect, the prevailing idiocy $[\ldots]$ these structures are testimony to the faith in science and technology, the practice of which has brought the world to a point of crisis that nobody knows how to resolve. ${ }^{34}$ 
Art Critic and Historian Maurice Berger outlines Morris' response to these conditions in his article 'Wayward Landscapes', published in the catalogue to Morris' Retrospective at the Guggenheim Museum in New York in 1994. In the text, Berger focuses on an article the artist published in Artforum in 1975 after a visit to Peru to visit the Nasca Lines, large scale ancient drawings formed of geometric patterns and representations of animals located in the Nazca Desert. Berger states that Morris 'saw in the Nazca Lines "something intimate and unimposing," something that could help us to rethink the way our bodies relate to the world' ${ }^{35}$ He goes on to say that Morris felt that:

Nazca could serve as the model for aesthetic experiences that return to the individual those processes of perception and cognition lost through scientific or mathematical thinking. This freedom, he reasoned, was contradicted by the logic, geometry, and abstraction of 1960s Minimalist space [...] orientated to the vertical axis of urban, industrialized space. ${ }^{36}$

The Peru experience for Morris here becomes a means to critique what he sees as the continued focus of Western art on the Cartesian experience, where art exists 'as algebraic classifications, topological geometries, etc [...] a faintly academic exercise. ${ }^{37}$

For Morris this shift in the Minimalist aesthetic of the diagram, with its emphasis on surface, mirrors the historical desire of Western civilisations to control nature; where the physical world was reduced to written and drawn notations as scientific progress came to play a leading role in the Enlightenment discourse and thought of the eighteenth century. ${ }^{38}$ He states again in his article 'Aligned with Nazca' that:

The act of counting invented time. The periodic recurrences of an object in space (the moon) were fixed by marks on a surface. Thus notation began its long march through the history of humankind, functioning not only to record and control but to shut out the physical world. ${ }^{39}$ 
This assertion against too heavy a reliance on technology, technocracy and the sciences could also be said to be reflected in the importance of process in his works, which in his 1968 essay 'Anti Form' he frames as: 'Chance is accepted and indeterminacy is implied. The focus on matter and gravity as means results in forms that were not projected in advance. Considerations of ordering are necessarily casual and imprecise [...] passing form to the material" A resonant condition that marks a poetics of softness'. ${ }^{40}$

\section{Celestial Mark Making}

Raimund Abraham was less explicit than Morris when discussing his projects and the potential effects of the scientific and technological developments of the 1960s and 1970s on our understanding of the environment. However, it is worth noting that his work shifted dramatically away from the utopian, technologically machinist megastructures he was designing in the mid- to late1960s towards a poetic investigation of the connection between landscape, architecture, home and body. ${ }^{41} \mathrm{~A}$ move which saw the emphasis put on simple geometrical structures that are semi-buried and open to the elements themes that run through all of his vivid and visionary projects form the 1970s, such as 10 Houses $(1970-1973)$. They are also forms that, like those of Morris, might be said to resonate with ancient architectures such as burial mounds and celestial chapels. ${ }^{42}$ For critic and theorist Kenneth Frampton, these works were 'in effect, an earth work, cut into the dormant but still fecund soil. ${ }^{43}$ As well as a 'conscious recognition of omnipotent cosmic forces' ${ }^{4}{ }^{4}$

Framing this work was Abraham's key concern that architecture 'primarily' exists as an act of a collision with its site and with the landscape where it was sited. In an interview, again with Frampton, Abraham stated that architecture 'addresses itself to the archetypical site of the horizon where the earth meets the sky. Any architectural endeavor is an interference with this site. ${ }^{45}$ Further in the interview, Abraham elaborates on what form this collision might take stating, "I think it is possible to develop a taxonomy of collisions in 
architecture; the collision of the object with time', ${ }^{46}$ and 'the collision of the "site or the architecture with light". 47

It was an idea that we can see manifest in designs such as House With Permanent Shadow (1972). (Fig. 17) The proposal is formed from several components including a buried structure with a gridded glass roof and a wall that protrudes from the ground into the sky that cast a lengthy shadow across the roof of the building and the ground beside it. Because of the scale of the shadow and the way the building is drawn, it is difficult to read what is the physical structure of the architecture and what is the cast shadow - a treatment that suggests Abraham's architecture is formed as much from the materials used to create it, such as concrete and glass, as it is from the processes such as the movement of the sun.

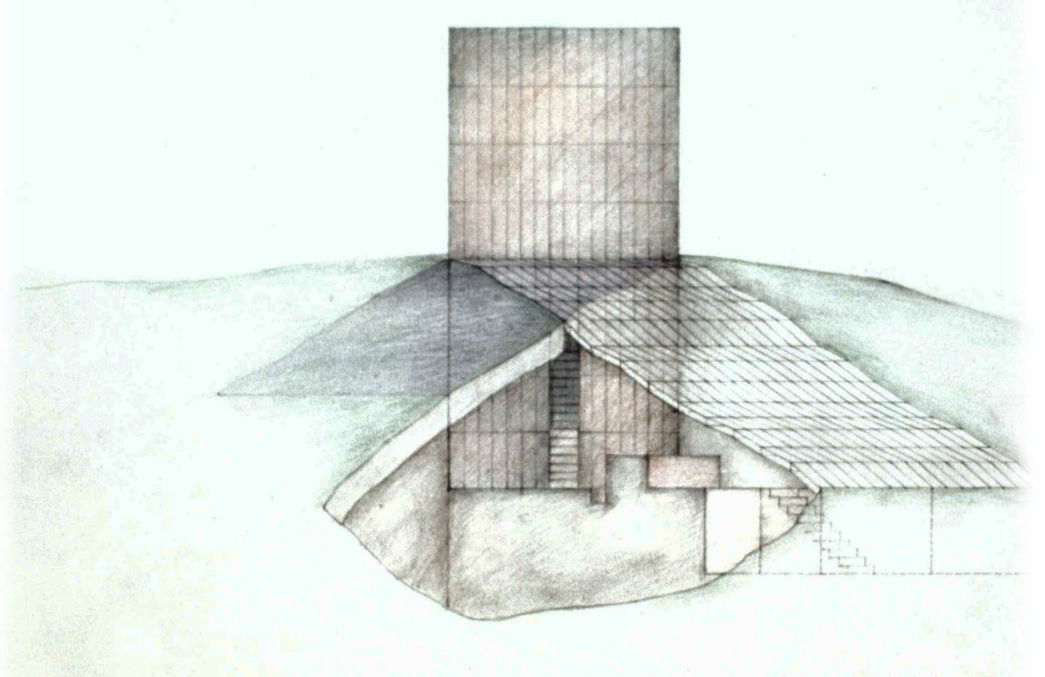

Fig. 17: Raimund Abraham, House with Permanent Shadow, 1971, Courtesy of the Archive of Raimund Abraham. *Copyright to be confirmed.

Although not necessarily critical of an increase in technological prowess like that seen in the work of Morris or in the Measure House and Bang Bang House, Abraham was clearly concerned with architecture's relationship to and effect on the environment. It was a concern made manifest with declarations in lectures he gave throughout his career. In a lecture given for the international competition to design the New Acropolis Museum in Athens in 
1991, he declared, 'We live in a time, when the air we breathe is so poisonous that we destroy the sculptures of our ancestors. ${ }^{48}$ Or in a text written for an exhibition in Graz, Austria in 1989 he writes that, 'Architecture must remind itself, how vulnerable the surface of the Earth has become'. ${ }^{49}$ Within these statements he seems to be fully aware of the need for architecture to operate as a means to question the nature of humans' occupation of the earth.

The poetics of questioning how we inhabit the earth resounds through the speculative designs of Bang Bang House and Measure House which aim to make those occupying them aware of their own physicality and physical experiences. In the Measure House this occurs in the way the building controls its internal temperatures. In the Bunker Room, a room located at the north-western wing of the house, the structure is formed from two-metre-thick walls. The temperature within this space rarely alters, remaining primarily chilled as heat cannot easily penetrate it. Entering this space on a hot day, occupants are thus immediately made more aware of the heat outside. Conversely, on a cold day in winter, their bodies will not feel the comfort normally associated with the interior spaces of a tradition house or home. In the Felt Room, at the opposite end of the structure to the Bunker Room, the control of heating and cooling is quite different. Here the fabric construction of its walls generates temperatures similar to those in the shade outside the building. It is an open space in which to directly experience the environment, including changes in temperature and weather patterns as day turns to night and summer to winter. This temperature shift is visibly represented in the plans of heat patterns, reacting to the shade and shadow created by the structure, in and around the building. (Fig. 18.1 and Fig. 18.2) Here the drawings graphically illustrate the different temperature shifts that would occur at different times of the year, in different weather conditions, including with and without cloud cover, and in different areas of the building. ${ }^{50}$ 

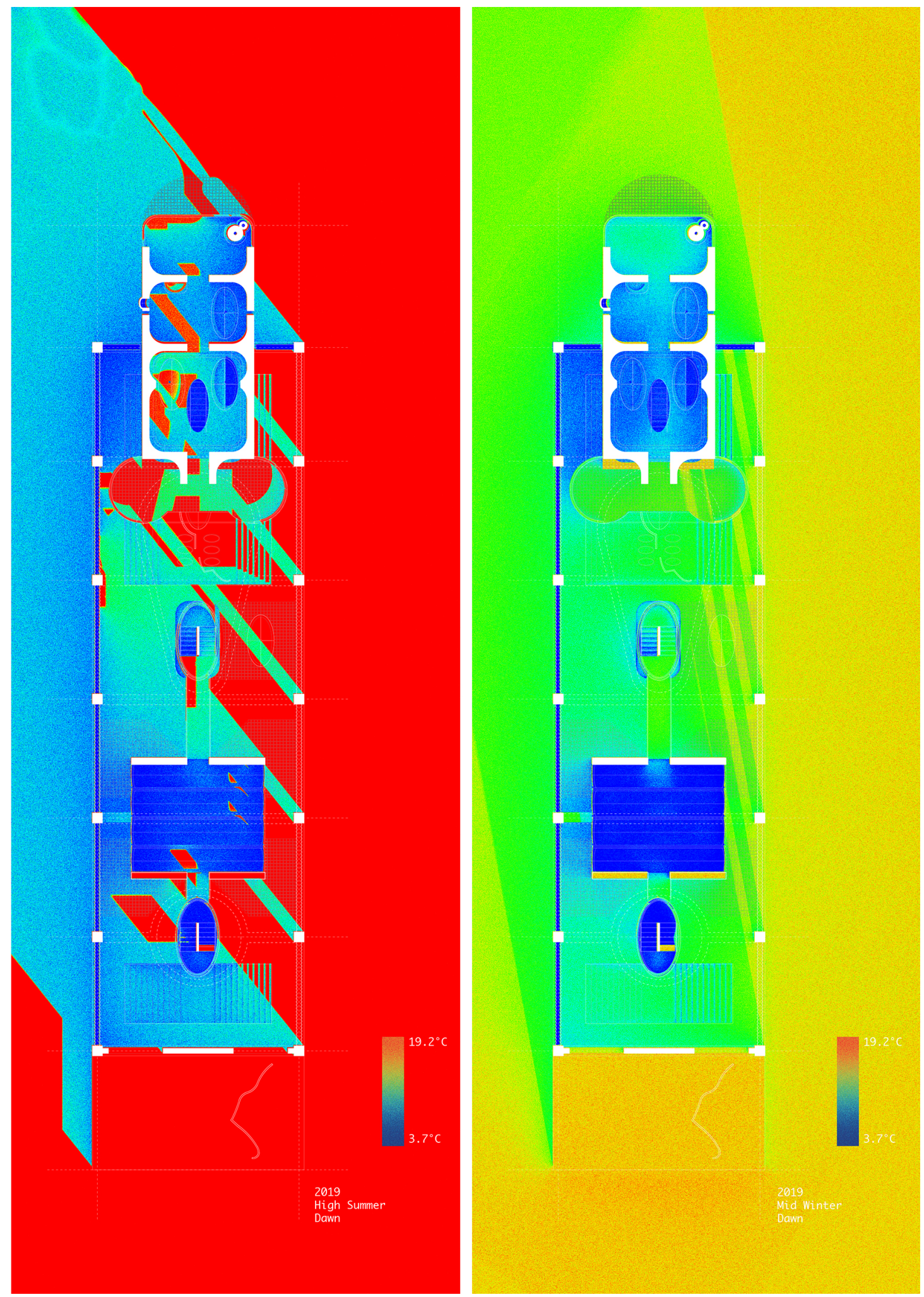


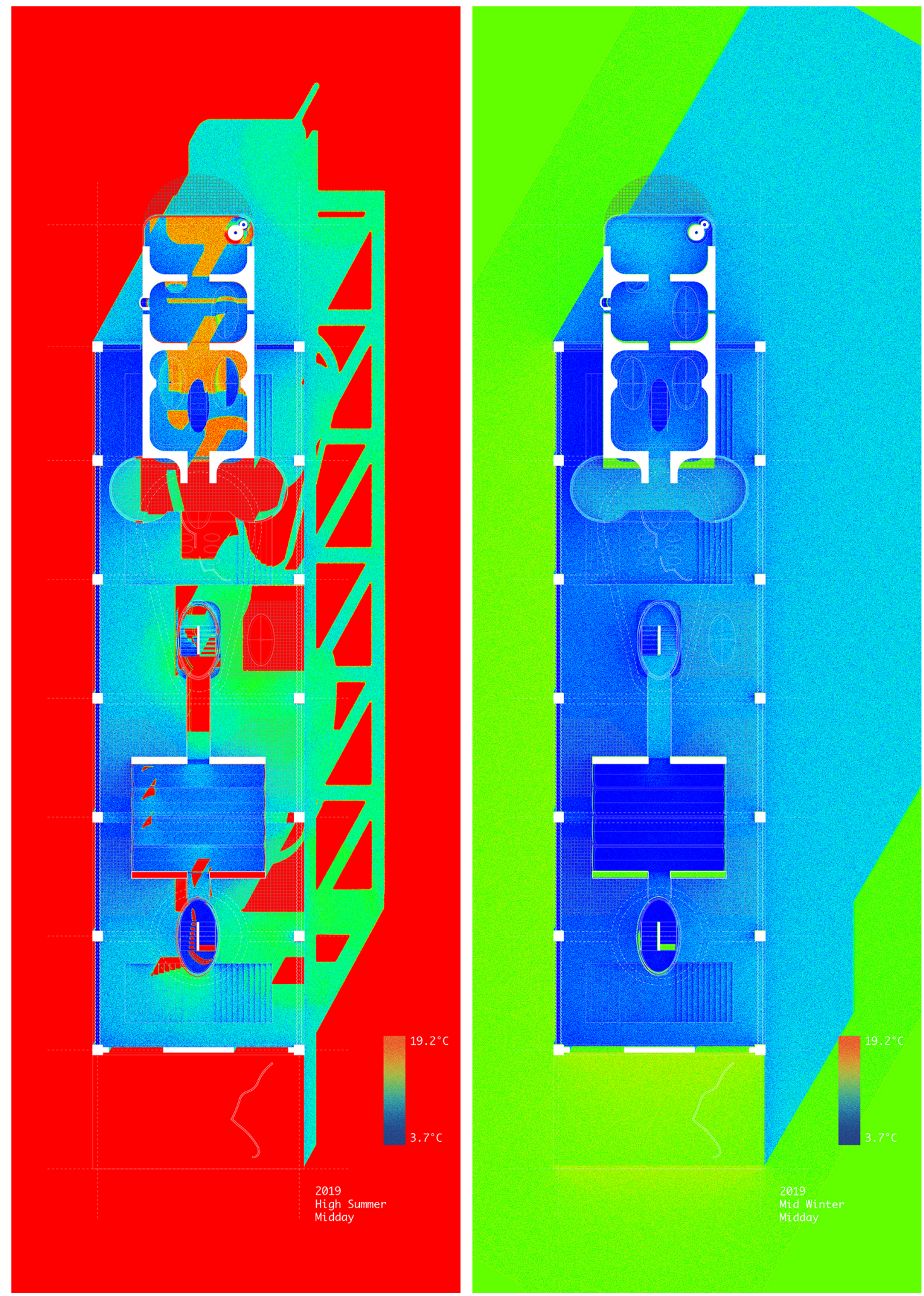

Fig. 18.1: Author, Heat Map in Measure House, Lizard peninsula, Cornwall: Plans, 2017. From left to right: High Summer Dawn, 2019 - Mid Winter Dawn, 2019.

Fig. 18.2h: Author, Heat Map in Measure House, Lizard peninsula, Cornwall: Plans, 2017. From left to right: High Summer Midday, 2019 - Mid Winter Midday, 2019. 
The juxtaposition of these two contrasting rooms in the Measure House allows for a certain degree of choice as to which of the different environments to occupy. In deciding which is best suited to their requirements, occupants need to form an awareness of the conditions they are experiencing and consider how these might have changed from the previous day or previous year due to the effects of global warming. They might, for example, find themselves occupying the Bunker Room more frequently during the summer, remembering that the previous year the rise in temperature had made sleeping in other parts of the house unbearable. This form of dwelling thus contradicts the non-conscious, habitual mode of living in buildings that can more easily control their interior environments, for example with central heating or air conditioning that promote stable conditions that attribute comfort. Instead, the Measure House temperature control creates occupation that at times would be uncomfortable.

\section{Evoking the Human and the passing of time}

This movement of occupiers through Measure House as they try to find areas of comfort illustrates how it is more than a frame through which celestial movements can be passively observed. Rather, both it and Bang Bang House form a central element in a display of Performance Art as they drive and direct the experience of the occupiers, just as visitors to Morris' Observatory climb through and over the ramparts. Each building acts as a canvas on which the occupiers seek to engage in an understanding of the forces that govern our physical lives, such as gravity, because of the way movement is restricted across the constructed terrains. This condition is exaggerated as there are, in both houses, several spaces allocated for living, but there are no designated rooms for particular functions; occupants are instead encouraged to wander through the structure and locate and use spaces they feel most comfortable in to rest, work or eat. In the Measure House the rooms are organised around a series of vertical floors, surfaces and levels that need to be accessed via winding staircases, the treads of which are higher than is usually found in domestic accommodation, thus making it harder and slower to move between the different spaces. In the Bang Bang House, occupants are required to 
climb ladders or negotiate steep, curved undulated floors to reach the spaces or rooms they wish to access.

These design traits create increased physical resistance to bodily movement within the buildings, which means a greater degree of physical exertion is required for the day-to-day occupation of them, thus enhancing and making more apparent the experience of gravity. The occupants' experience of this natural force, translated into their exaggerated movements through the building, resonates with Gianni Pettena's work from the late 1960s and 1970s in which he made visible the forces of climate in urban and suburban America.

The aim of this work was to encourage debate about human impact on the environment ${ }^{51}$ by focusing on the ability of natural systems to cause processes of change in materials in familiar settings. We see this occurring in Clay House (1972) (Fig. 19) a project located in Salt Lake City, Utah, in which a traditional nineteenth-century suburban house was covered in clay; a process that distorted the overall appearance of the house into a hybrid of something recognisable, as the outline of the original house, but different through the application of the new material. A similar effect is also present in works such as Ice House I (1971), a structure formed of ice that covered an abandoned school in a suburb of Minneapolis. Both structures were transformed by environmental conditions: Ice House I thawed and melted when temperatures rose in the spring, and Clay House dried and cracked over the summer months of 1972. As the effect of the climate became visualised, both structures distorted the familiar forms and materials of the buildings that lay behind Pettena's manipulations, the uncanny depiction accentuating the possible destructive effect of the weather. Describing these works, Pettena states in an interview with Emanuele Piccardo in 2014, that 'By adopting nature as the director of the game I also tried to make a statement: that nature and not man is the director of all strategies. Man can only make gestures of violence against nature. ${ }^{.52}$ 


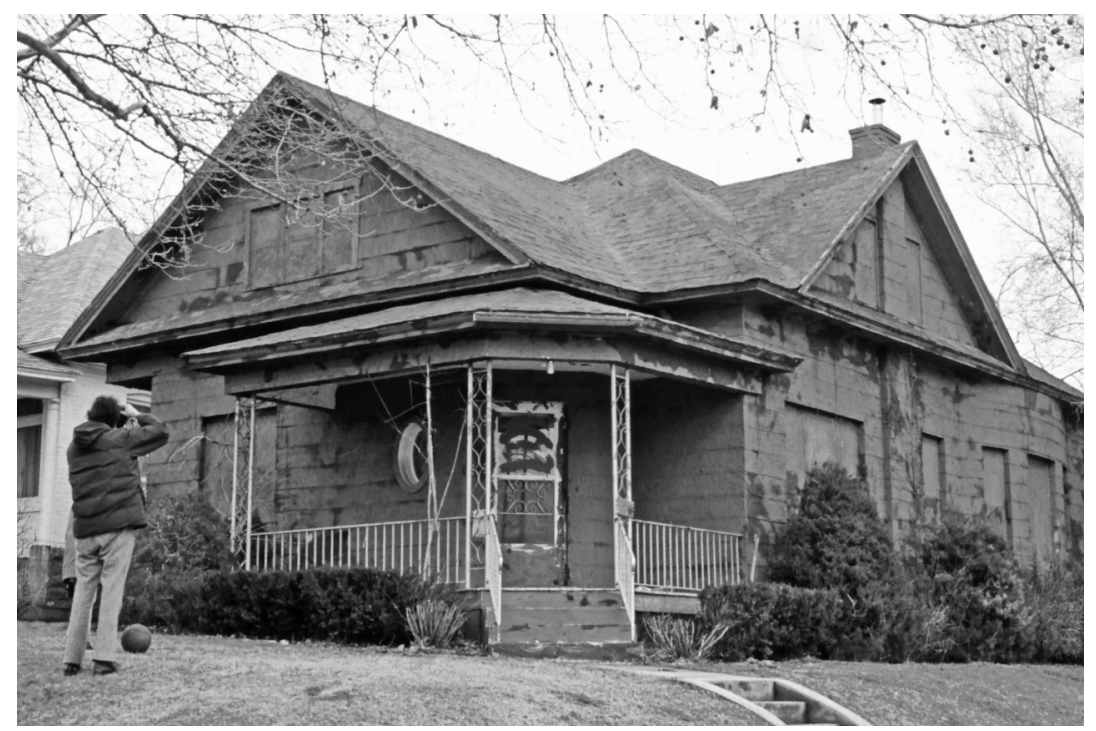

Fig.19: Gianni Pettena, Clay House, 1972. Courtesy of Gianni Pettena Studio.

In Ice House I and Clay House, the transformation of the active materials sought to question our relationship with the homes we build, the cultures these create, and our growing detachment from our experience of the world: 'The moment you build a wall [...] you become fixed in a place so you aren't integrated with nature anymore but nature becomes your counterpart. ${ }^{, 53}$

Through Abraham's interventions, this poetic interaction between the building, the location and the climate emerges obliquely. In the Clay House, it is as summer turns to high summer and the clay cracks and falls away; the freezing of the water façade in the Ice House in the cold winter and then it's thawing as temperatures rise in the spring, manifest these climatic changes. This is mirrored in the collection of sediment as tides rise and fall in the Reed House and the way sound in the Bang Bang House records the rise and fall of the tide. But where the Measure House, like Morris' Observatory and Abraham's House with A Long Shadow, provides an explicit interaction and canvas on which the temporal shifts in the sun's path can be displayed, the material changes in Pettena's work only expresses these celestial movements indirectly. Instead, it is the effects of time in and on matter that signals change. Here the witnessed shifts in material follow Kozloff's notion that the poetics of softness 'mimes a kind of surrender to the natural condition that pulls bodies down', ${ }^{4}$ such as time and gravity, which he states 'will unavoidably invoke the human'. ${ }^{55}$ Within this, it is not the body that feels the effects of celestial movement directly, instead it is the material change in 
these projects that mimics the body, reminding us of our inherent softness, fragility and ultimately our own entropy.

\section{Conclusion}

This essay has presented two distinct design projects, the Measure House and the Bang Bang House, in relation to the ideas of Max Kozloff and the work and writings of artists Robert Morris, Raimund Abraham and Gianni Pettena, in order to present a model for a unique architecture of softness. It is a softness that is defined by the performative and poetic characteristics that the projects embody and represent; a condition that creates a dynamic, emotive and expressive architecture which links the experiences of the action of design to those that view and inhabit them. It is also a condition that frames and encapsulates the complex multi-scalar ecological events that link movements of celestial bodies and global weather patterns to the specific experience of the individual and the sites we choose to inhabit. Through these different lenses, the Measure House and Bang Bang House provide a distinct model of architecture that acts as a provocation to erode our reliance on the didactic and abstract mechanisms of the numerical and algorithmic processes that control our buildings. Distinct operations that reduce our experience of our climate, and society, to numbers and data in the pursuit of an arbitrary, transitory comfort. Instead, Measure House and Bang Bang House suggest an architecture of discomfort, transience and action - conditions which engage the body with the building, and thus seek to evoke a more human, and with this a more empathetic and soft, relationship with the world we inhabit.

\section{Footnotes:}

Using : http://www.mhra.org.uk/style/11

1. Intergovernmental Panel on Climate Change, Climate Change 2014: Synthesis Report Summary for Policymakers, p. $2<$ https://www.ipcc.ch/site/assets/uploads/2018/02/AR5_SYR_FINAL_SPM.pdf> [accessed 26 March 2019). Report states that 'Human influence on the climate system is clear, and recent 
anthropogenic emissions of green-house gases are the highest in history. Recent climate changes have had widespread impacts on human and natural systems.'

2. Mike Hulme, Why We Disagree About Climate Change: Understanding Controversy, Inaction and Opportunity (Cambridge: Cambridge University Press, 2009).

3. Hulme, p. 52.

4. Hulme, pp. 44-66.

5. There are many sources we could use to illustrate this point but critically it is intrinsic to developments of European Union (EU) policy towards building design and energy usage. See: Directive 2002/91/EC of the European Parliament and of the Council of 16 December 2002. And Directive (EU) 2018/844 of the European Parliament and of the Council of 30 May 2018 amending Directive 2010/31/EU on the energy performance of buildings and Directive 2012/27/EU on energy efficiency <https://eur-lex.europa.eu/legal-

content/EN/TXT/PDF/?uri=CELEX:32018L0844\&from=EN> [accessed 22 April 2019]. Please also see sustainability design frameworks: BREEAM, Technical Manual: Version: SD5078 Issue: $2.0,2018$ <https://www.breeam.com/NC2018/> [accessed 21 April 2019] and LEED v4 for Building Design and Construction, U.S Green Building Council, July 2, 2018.

6. Please see the emphasis placed by the EU policy towards building design and energy usage on a desire for automated environmental control systems in: Jaap Hogeling and Anita Derjanecz, 'The 2nd recast of the Energy Performance of Buildings Directive (EPBD)', REHVA Journal, 2018 <https://www.rehva.eu/publications-and-resources/rehvajournal/2018/022018/the-2nd-recast-of-the-energy-performance-of-buildings-directiveepbd.html> [accessed 22 April 2019]

7. In many regulatory, policy and good practice documentation notions of insuring comfort are set as paramount to the specification of any building design. Comfort in these circumstances is again defined by specific parameters. For an example of this please see documents such as CIBSE Guide A, Table 1.5 from: CIBSE Guide A: Environmental Design, $8^{\text {th }}$ edition, 2015. Although there must be recognition that these particular parameters for comfort are necessary for health and well-being the arguments presented in this ARQ article are designed as a polemic against such measures suggesting instead that I would suggest that we need to feel uncomfortable in light of the threat form global warming.

8. Alberto Pérez-Gómez, Architecture and the crisis of Modern Science (Cambridge, MA and London: MIT Press, 1983).

9. Pérez-Gómez, p.6.

10. Max Kozloff, Renderings: Critical Essays on a Century of Modern Art (London: Studio Vista, 1969), pp. 223-36.

11. Met Office, 'South West England: Climate' (2016)

<https://www.metoffice.gov.uk/climate/uk/regional-climates/sw> [accessed 18 May 2018].

12. Bill McGuire, 'Will Global Warming Trigger a New Ice Age?', The Guardian, 13 November

$2003<$ https://www.theguardian.com/environment/2003/nov/13/comment.research> [accessed 18 May 2018].

13. McGuire, 'Will Global Warming Trigger a New Ice Age?'.

14. Clive Cookson, 'Global Warming to Give Colder Winters and Hotter Summers', Financial Times, 11 April 2018 <https://www.ft.com/content/997d057e-3d6b-11e8-b7e0-52972418fec4> [accessed 10 July 2018].

15. An earlier version of this design was exhibited as part of exhibition: Alistair Robinson (Cur.), 'North and South', Northern Gallery of Contemporary Art, 11 July - 22 September 2007.

16. Michael Compton and David Sylvester, Robert Morris: Catalogue of an Exhibition Held at the Tate Gallery, 28 April - 6 June 1971 (London: Tate Gallery, 1971), p. 105.

17. Suzaan Boettger, Earthworks: Art and the Landscape of the Sixties (Oakland, CA: University of California Press, 2004), p. 25.

18. Compton and Sylvester, p.115. First published in Robert Morris, 'Some Notes

on the Phenomenology of Making: The Search for the Motivated', Artforum, 8 (1970), pp. 6266.

19. Compton and Sylvester, p. 115.

20. Paul Schimmel, 'Leap into the Void: Performance and the Object', in Out of Actions:

Between Performance and the Object 1949-1979, ed. Paul Schimmel (London: Thames \& Hudson, 1998), p. 17. 
21. Rosalind Krauss, 'The Mind/Body Problem: Robert Morris in Series', in Robert Morris: The Mind/Body Problem, ed. Rosalind Krauss and Thomas Krens (New York: Solomon R.

Guggenheim Foundation, 1994), p. 6.

22. Krauss, p. 13.

23. Kozloff, p. 223.

24. Kozloff, p. 224.

25. Ibid

26. Ibid

27. Raimund Abraham, 'The Reality of the Unbuilt', in Raimund Abraham: [Un]built, ed. Brigitte Groihofer (Vienna: Springer-Verlag, 2011), p. 110. The 'Chapter' lecture given by Abraham in Vienna in 1986 was part of a series organised by the Austrian Museum of Applied Arts.

28. Abraham, 'The Reality of the Unbuilt', p. 111.

29. Raimund Abraham, 'In Anticipation of Architecture: Fragmentary Notes', in Groihofer, Raimund Abraham: [Un]built, pp. 101.

30: Drawings were created using V-ray for 3D drawing programme Rhino, using the geographical sun element in Rhino for accurate representations of lighting.

31. Krauss, p. 12.

32. Morris, Continuous Project, p. 69. First published in Robert Morris, 'Notes On Sculpture Part 4: Beyond Objects', Artforum, 7 (1969), pp. 50-55.

33. Robert Morris, Continuous Project Altered Daily: The Writings of Robert Morris (Cambridge, MA and London: MIT Press and New York: Solomon R. Guggenheim Museum,1993), p. 211. First published in Robert Morris, 'Notes on Art as/and Land Reclamation', Art in America, 12 (1980), pp. 87-102.

34. Morris, Continuous Project, p. 229.

35. Maurice Berger, 'Wayward Landscapes', in Robert Morris: The Mind/Body Problem, ed. Rosalind Krauss and Thomas Krens (New York: The Solomon R. Guggenheim Foundation, 1994), p. 18.

36. Berger, p.18.

37. Morris, Continuous Project, p. 159. First published in Robert Morris, 'Aligned with Nazca', Artforum, 14 (1975), pp. 26-39).

38. Morris, Continuous Project, pp. 166-69.

39. Morris, Continuous Project, pp. 168-69.

40. Morris, Continuous Project, p. 46. First published in Robert Morris, 'Anti Form', Artforum, 6 (1968), pp. 33-35).

41. See Norbert Miller, 'Imagination and the Calculus of Reality: Raimund Abraham's

Architectural Oeuvre', in Groihofer, Raimund Abraham: [Un]built, p. 10. See also works by Abraham such as Metropolitan Core, c. 1963/64.

42. Anne Reynolds, Robert Smithson: Learning from New Jersey and Elsewhere (Cambridge, Mass.; London: MIT Press, 2003) p.145.

43. Kenneth Frampton, 'Fragmentary Notes', in Groihofer, Raimund Abraham: [Un]built, p. 216

44. Ibid

45. Kenneth Frampton and Raimund Abraham, 'Nine Questions to Raimund Abraham', in Groihofer, Raimund Abraham: [Un]built, p. 218

46. Ibid

47. Ibid

48. Raimund Abraham, 'The Silence of the Muses', in Groihofer, Raimund Abraham: [Un]built, p. 105. Text of a lecture given for the international competition to design the New Acropolis Museum, Athens, 1991.

49. Raimund Abraham, 'Speechless', in Groihofer, Raimund Abraham: [Un]built, p. 104.

50: Drawings should be seen as pictorial rather than representational of a computationally climatically modelled assessment of the buildings microclimate. They illustrate the undulations in heat across the building in relationship to the light and shadow that would be created. They were created using V-ray for Rhino, using the geographical sun element in Rhino for accurate representations of lighting. This record was then altered in Photoshop using gradient mapping. The temperature scale on the drawings was ascertained from using mean high and low temperatures from the geographical location of where the building is proposed. Please see: https://www.metoffice.gov.uk/public/weather/climate/gbukbmeyr [assessed 12 May, 2019] 
51. Emanuele Piccardo and Amit Wolf, Beyond Environment (New York: Actar, 2014), p. 111.

52. Ibid

53. Ibid

54. Kozloff, p. 224

55. Kozloff, p. 224

\section{Figures and Design Images}

Please note: Images are at a lower resolution than would be supplied for publication.

\section{Image Captions:}

Fig. 1: Author, Measure House, Lizard peninsula, Cornwall: exploded isometric, 2017.

Fig. 2: Author, Measure House, Lizard peninsula, Cornwall: plans and elevations, (2017).

Fig. 3: Author, Measure House, Lizard peninsula, Cornwall: isometric, 2017.

Fig. 4: Author, Measure House, Lizard peninsula, Cornwall: site plan, 2017.

Fig. 5: Author, Bang Bang House, Holehaven Creek, Thames Estuary: exploded isometric, 2017.

Fig. 6: Author, Bang Bang House, Holehaven Creek, Thames Estuary: site isometric, 2017.

Fig. 7: Author, Isometric Reed House with Sediment Nets and Sediment Banks, Holehaven Creek, Thames Estuary: isometric, (2004 - 2017).

Fig. 8: Author, Wobble Drawing 009 with element extractions, 2017.

Fig. 9: Author, Detail Bang Bang House, Holehaven Creek, Thames Estuary: isometric, 2017.

Fig. 10: Author, Wobble Drawing 006 as element extractions, 2017.

Fig. 11: Author, Isometric Interior of Measure House Sanctuary Space, Lizard peninsula, Cornwall: exploded isometric, 2017.

Fig. 12: Robert Morris, Blind Time I (1976). Copyright Courtesy of the Artist and Leo Castilli Gallery. ${ }^{*}$ Copyright to be confirmed.

Fig. 13: Author, Movement of Shadows in Measure House, Lizard peninsula, Cornwall: isometric, 2017.

Fig. 14.1: Author, Movement of Shadows in Measure House, Lizard peninsula, Cornwall: Plans, 2017. From left to right: High Summer Dawn, 2019 - Mid Winter Dawn, 2019.

Fig. 14.2: Author, Movement of Shadows in Measure House, Lizard peninsula, Cornwall: Plans, 2017. From left to right: High Summer at Midday, 2019 - Mid Winter at Midday, 2019.

Fig. 15: Author, Bang Bang House, Holehaven Creek, Thames Estuary, 2017. Sound graph shows relationship of the banging in the house caused by the strength of the tidal currents at different times of the day and month. Graph shows the relationship of this change in tide to the effect this would have on the sound the house makes at each minute.

Fig. 16: Robert Morris, Observatory (1971). Copyright Courtesy of Leo Castilli Gallery. ${ }^{*}$ Copyright to be confirmed. 
Fig. 17: Raimund Abraham, House with Permanent Shadow, 1971, Courtesy of the Archive of Raimund Abraham. *Copyright to be confirmed.

Fig. 18.1: Author, Heat Map in Measure House, Lizard peninsula, Cornwall:

Plans, 2017. From left to right: High Summer Dawn, 2019 - Mid Winter Dawn, 2019.

Fig. 18.2h: Author, Heat Map in Measure House, Lizard peninsula, Cornwall: Plans, 2017. From left to right: High Summer Midday, 2019 - Mid Winter Midday, 2019.

Fig.19: Gianni Pettena, Clay House, 1972. Courtesy of Gianni Pettena Studio. 